\title{
Tifton 85 grass responses to different nitrogen levels and cutting intervals
}

\section{Características estruturais e composição bromatológica de capim tifton 85 sob doses de nitrogênio e idades de rebrota}

\author{
Loreno Egidio Taffarel ${ }^{1 *}$; Eduardo Eustáquio Mesquita ${ }^{2}$; \\ Deise Dalazen Castagnara ${ }^{3}$; Sandra Galbeiro ${ }^{4}$; \\ Patricia Barcellos Costa ${ }^{2}$; Paulo Sérgio Rabello de Oliveira ${ }^{2}$
}

\begin{abstract}
The objective of this study was to evaluate the influence of five levels of $\mathrm{N}$ and two regrowth intervals on the structural, productive, and nutritional characteristics of Tifton 85 grass (Cynodon spp). The experiment was conducted in a hay production field at the State University of West Paraná, planted in 2004 with Cynodon spp. cv. Tifton 85. The experiment was established in a randomized block design with factorial treatments of five $\mathrm{N}$ fertilization amounts $\left(0,25,50,75\right.$ and $\left.100 \mathrm{~kg} \mathrm{ha}^{-1} \mathrm{cut}^{-1}\right)$ applied as urea after each cut, and two regrowth intervals ( 28 and $35 \mathrm{~d}$ ), with four replicates. $\mathrm{N}$ application promoted changes in plant structure, such as increased canopy height, stem length, leaf elongation rate, and dry mass $(\mathrm{DM})$ production. The greatest $\mathrm{N}$ use efficiency, considering the four harvests, occurred in the plot with $25 \mathrm{~kg} \mathrm{~N} \mathrm{ha}^{-1} \mathrm{cut}^{-1}$ at the $35-\mathrm{d}$ interval, with a production of $13.79 \mathrm{~kg} \mathrm{DM} \mathrm{kg}^{-1}$ of N applied. A nutritional analysis indicated that $100 \mathrm{~kg} \mathrm{ha}^{-1}$ of $\mathrm{N} \mathrm{cut}^{-1}$ promoted higher crude protein $(\mathrm{CP})$ at $28 \mathrm{~d}$, with the highest concentration observed in the fourth cut $\left(208.2 \mathrm{~g} \mathrm{~kg}^{-1} \mathrm{DM}\right)$ and the lowest in the second cut (140.12 $\left.\mathrm{g} \mathrm{kg}^{-1} \mathrm{DM}\right)$. The content average in the four cuts for CP and LIG at 28 days of regrowth was 175.85 and $104.33 \mathrm{~kg}^{-1} \mathrm{~g}$ MS and at 35 days of regrowth interval was of 164.45 and $118.65 \mathrm{~g} \mathrm{~kg}^{-1} \mathrm{DM}$, respectively. No differences were found between regrowth intervals in the contents of mineral matter and acid detergent fiber (ADF). Environmental factors including the wide variation in precipitation (greater than $200 \mathrm{~mm}$ between the peak in December 2010 and the lowest in March 2011) greatly influenced Tifton 85 grass production, affecting DM and the nutritional value of the forage in each cut. Key words: Biomass. Forage quality. Grazing. Management. Persistence. Stocking.
\end{abstract}

\section{Resumo}

O objetivo do trabalho foi avaliar a influência de cinco doses de nitrogênio $(\mathrm{N})$ em duas idades de rebrota no capim Tifton 85 (Cynodon spp.) sobre as características estruturais, produtivas e na composição bromatológica. O experimento foi instalado no campo de produção de feno da UNIOESTE, campus de Marechal Cândido Rondon. O delineamento experimental foi em blocos casualizados em esquema fatorial 5x2, sendo cinco doses de nitrogênio $\left(0,25,50,75\right.$ e $\left.100 \mathrm{~kg} \mathrm{ha}^{-1}\right)$ aplicados em cada corte, aplicadas na forma de uréia, duas idades de rebrota ( 28 e 35 dias) com quatro repetições e quatro cortes.

1 Médico Veterinário, M.e em Zootecnia, Dr. em Agronomia, Universidade Estadual do Oeste do Paraná, UNIOESTE, Marechal Cândido Rondon, PR, Brasil. E-mail: loreno.taffarel@gmail.com

2 Profs., Centro de Ciências Agrárias, UNIOESTE, Marechal Cândido Rondon, PR, Brasil. E-mail: e-mesquita@bol.com.br; patriciabarc@hotmail.com; rabello.oliveira@hotmail.com

3 Prof ${ }^{a}$ Adjunto, Universidade Federal do Pampa, UNIPAMPA, Uruguaiana, RS, Brasil. E-mail: deisecastagnara@yahooo.com.br

4 Prof $^{a}$ Dr $^{\mathrm{a}}$ Adjunto A, Departamento de Zootecnia, Universidade Estadual de Londrina, CCA/UEL, Londrina, PR, Brasil. E-mail: sgalbeiro@gmail.com

Author for correspondence 
As doses de nitrogênio promoveram alterações nas características estruturais das plantas, como maior altura do dossel, comprimento de colmo, taxa de alongamento das folhas e produção de MS. A maior eficiência de utilização de $\mathrm{N}$ ocorreu na dose de $25 \mathrm{~kg} \mathrm{~N}^{-1}$ corte $^{-1}$, com 13,79 $\mathrm{kg}^{-}$de MS kg-1 de N aplicado na idade de rebrota de 35 dias. Na composição bromatológica a dose de $100 \mathrm{~kg} \mathrm{~N}^{-1}$ corte $^{-1}$ promoveu maior teor de proteína bruta na idade de 28 dias, sendo que a maior concentração ocorreu no quarto corte $\left(208,2 \mathrm{~g} \mathrm{~kg}^{-1} \mathrm{MS}\right)$ e a menor no segundo corte $\left(140,12 \mathrm{~g} \mathrm{~kg}^{-1} \mathrm{MS}\right)$. Os teores médios considerando os quatro cortes de proteína bruta e lignina foram de 175,85 e $104,33 \mathrm{~g} \mathrm{~kg}^{-1}$ MS aos 28 dias e de 164,45 e 118,65 $\mathrm{g} \mathrm{kg}^{-1} \mathrm{MS}$ aos 35 dias de intervalo de corte, respectivamente. Não houve diferenças entre idades na concentração de matéria mineral e de fibra em detergente ácido. A grande variação de precipitação (superior a $200 \mathrm{~mm}$ entre o mês com maior e menor precipitação) influenciou na produção de MS e na produção total de PB por corte.

Palavras-chave: Biomassa. Lotação. Manejo. Pastejo. Persistência. Qualidade das forrageiras.

\section{Introduction}

Balanced $\mathrm{N}$ fertilization can increase pasture productivity and sustainability and reduce environmental impacts by limiting pasture degradation especially if fertilizer is applied in a species-specific manner. Grazing systems must be carefully managed according to the carrying capacity of the pasture to maintain dry matter (DM) production and sustain the system (MOREIRA et al., 2015); management may include increasing the supply of nutrients and possibly integrating crops and livestock (SOLLENBERGER, 2008). N limits biomass production and influences the amount of other nutrients necessary to sustain production. It also influences the nutritional value of forage, plant health, and plant recovery after grazing, and may affect animal performance (SOLLENBERGER, 2008; SILVA et al., 2013).

$\mathrm{N}$ fertilizer must be applied regularly because the amount available in the soil is insufficient to support high productivity and forage quality (REZENDE et al., 2015). When applied regularly according to the cycling capacity of the forage crop and with respect to soil permeability and drainage, $\mathrm{N}$ can increase the productivity and concentration of animals per unit area, resulting in lower methane emissions per kilogram of milk or meat as slaughter age is reduced and milk production is increased (PEDREIRA; PRIMAVESI, 2006). More than three times the fossil fuel energy is required to provide the same energy to ruminants from soybean and corn compared to forage (TAMMINGA, 1996).
$\mathrm{N}$ fertilizer must be applied appropriately to enhance plant recovery, reduce runoff, and prevent the formation of nitrous oxide $\left(\mathrm{N}_{2} \mathrm{O}\right)$ (FERRÃO et al., 2010). More frequent but smaller doses reduce losses from volatilization, denitrification, and leaching, enabling better plant growth and maintenance (SILVA et al., 2013). Quaresma et al. (2011) found that biomass of Tifton 85 was markedly reduced after $\mathrm{N}$ application at an estimated dose of $155 \mathrm{~kg} \mathrm{ha}^{-1}$.

Sustainable production systems for Tifton 85 (Cynodon spp.) and Tifton 68 (Cynodon nlemfuensis) require soils with abundant nutrient levels. Tifton 85 is more tolerant of grazing because its rhizomes have many lateral buds and can store energy (SOLLENBERGER, 2008). It is more resistant to cold, frost, and drought than other cultivars of bermudagrass and can grow 6-8 months during the year, producing abundant and highly digestible forage (MONTEIRO et al., 2008), but this growth requires high $\mathrm{N}$, potassium, and soil moisture availability (ANDERSON et al., 2008). In the winter, pastures with Tifton 85 can be seeded with oats, providing year-round forage with a high protein content and digestibility (NERES et al., 2011).

After grazing, the regrowth interval affects the quality and morphogenesis of Tifton 85 . The leaf to stem ratio (LSR) reaches a maximum between 28 and $35 \mathrm{~d}$ and then decreases, owing to a decrease in the leaf appearance rate (LAR) and an increase in phyllochron and leaf senescence and death 
(PEREIRA et al., 2011). Moreira et al. (2015) found that the total tiller number $(\mathrm{TN}) \mathrm{m}^{-2}$ also increased as tiller weight (TW) decreased with increasing $\mathrm{N}$ application of $0-223 \mathrm{~kg} \mathrm{ha}^{-1}$.

The daily leaf elongation rate (LER) and leaf length (LL) are associated with the DM accumulation rate of leaf blades, which is higher in the summer. However, the LAR and the number of leaves per tiller are higher in spring (VILELA et al., 2005), and $\mathrm{N}$ influences these characteristics, contributing to increased DM yield, turf height, and crude protein $(\mathrm{CP})$ content, and reducing the neutral detergent fiber (NDF) content (QUARESMA et al., 2011).

$\mathrm{N}$ applications in Tifton 85 also increase the CP content (VENDRAMINI et al., 2008b) and digestibility (VENDRAMINI et al., 2008a). Therefore, a low $\mathrm{N}$ fertilization rate reduces the $\mathrm{CP}$ and rumen degradable protein (RDP) contents of grasslands, which can limit the performance of ruminants with higher $\mathrm{CP}$ requirements. Although a RDP supplement can be added to the animals' diet, even fertilization and appropriate grazing intervals are equally effective (SOLLENBERGER, 2008).

The livestock production systems in Brazil are constantly evolving and encompass a range of techniques, but intensive forage systems that use strategic supplementation have benefitted from the multidisciplinary knowledge of new professionals who are providing management improvements (LOBATO et al., 2014), and making production more sustainable (LATAWIEC et al., 2014). Demand for dairy cattle production has increased and could be met with carefully managed Tifton 85 .

The objective of this study was to evaluate the influence of five $\mathrm{N}$ treatments on the structural characteristics, productivity, chemical and bromatological composition, and digestibility of Tifton 85 harvested at two regrowth intervals.

\section{Material and Methods}

The experiment was conducted under field conditions at the Experimental Farm "Antonio Carlos dos Santos Pessoa," which belongs to the State University of West Paraná, Marechal Cândido Rondon campus (latitude: 24³3'40" S; longitude: $54^{\circ} 04^{\prime} 12^{\prime \prime} \mathrm{W}$; altitude: $420 \mathrm{~m}$ above sea level). The local climate is classified according to Koppen as the Cfa type, subtropical with well-distributed rainfall during the year and hot summers (CAVIGLIONE et al., 2000). The average temperature varies between 17 and $18{ }^{\circ} \mathrm{C}$ for the coldest quarter and between 28 and $29^{\circ} \mathrm{C}$ for the warmest quarter, with an annual temperature between 22 and $23{ }^{\circ} \mathrm{C}$. The average annual rainfall ranges from 1660 to 1800 $\mathrm{mm}$, with quarterly totals ranging from 400 to 500 $\mathrm{mm}$ (CAVIGLIONE et al., 2000). The climatic conditions during the experiment are shown in Figure 1.

The soil in the experimental area is classified as a eutrophic red latosol (ERL) (EMBRAPA, 2006) and has the following chemical characteristics: $\mathrm{P}$ (Mehlich extractor) $8.15 \mathrm{mg} \mathrm{dm}^{-3}$; OM $23.92 \mathrm{~g} \mathrm{dm}^{-}$ 3; $\mathrm{pH}\left(\mathrm{CaCl}_{2}\right) 0.01 \mathrm{~mol} \mathrm{~L}^{-1} ; \mathrm{H}+\mathrm{Al}=4.30 \mathrm{cmol}_{\mathrm{c}}$ $\mathrm{dm}^{-3} ; \mathrm{Al}^{3+}=0.05 \mathrm{cmol}_{\mathrm{c}} \mathrm{dm}^{-3} ; \mathrm{K}=0.23 \mathrm{cmol}_{\mathrm{c}} \mathrm{dm}^{-}$ 3. $\mathrm{Ca}^{2+}=3.62 \mathrm{cmol}_{\mathrm{c}} \mathrm{dm}^{-3} ; \mathrm{Mg}^{2+}=1.69 \mathrm{cmol}_{\mathrm{c}} \mathrm{dm}^{-3}$; $\mathrm{SB}=5.54 \mathrm{cmol}_{\mathrm{c}} \mathrm{dm}^{-3} ; \mathrm{CTC}=9.84 \mathrm{cmol}_{\mathrm{c}} \mathrm{dm}^{-3} ; \mathrm{V}$ $=56.30 \% ; \mathrm{Al}=0.89 \% ; \mathrm{Cu}=6.30 ; \mathrm{Mn}=1.4 ; \mathrm{Zn}=$ $63.00 ; \mathrm{Fe}=25.10 ;$ clay $=650 \mathrm{~g} \mathrm{~kg}^{-1}$.

The experiment was conducted in a hay production field planted in 2004 with Cynodon spp. cv. Tifton 85 . The experimental design was a completely randomized $5 \times 2$ factorial arrangement, with five $\mathrm{N}$ treatments $\left(0,25,50,75\right.$, and $100 \mathrm{~kg} \mathrm{ha}^{-1}$ cut $^{-1}$ ) and two regrowth intervals (28 and $35 \mathrm{~d}$ ), with four replicates and four crops (cuts). Experimental plots were $3 \mathrm{~m} \times 5 \mathrm{~m}$. The experiment began on October 30, 2010 with a uniform cut to within $5 \mathrm{~cm}$ of the soil and with fertilization of $40 \mathrm{~kg} \mathrm{ha}^{-1} \mathrm{~K}_{2} \mathrm{O}$ in the form of potash and $40 \mathrm{~kg} \mathrm{ha}^{-1} \mathrm{P}_{2} \mathrm{O}_{5}$ chloride in the form of superphosphate, following IAPAR (2003) recommendations for fodder fertilization. 
Figure 1. Temperature $\left({ }^{\circ} \mathrm{C}\right)$ (mean, maximum, and minimum) and precipitation (mm rainfall) during the experimental period (Marechal Cândido Rondon, October 30, 2010 to March 21, 2011).

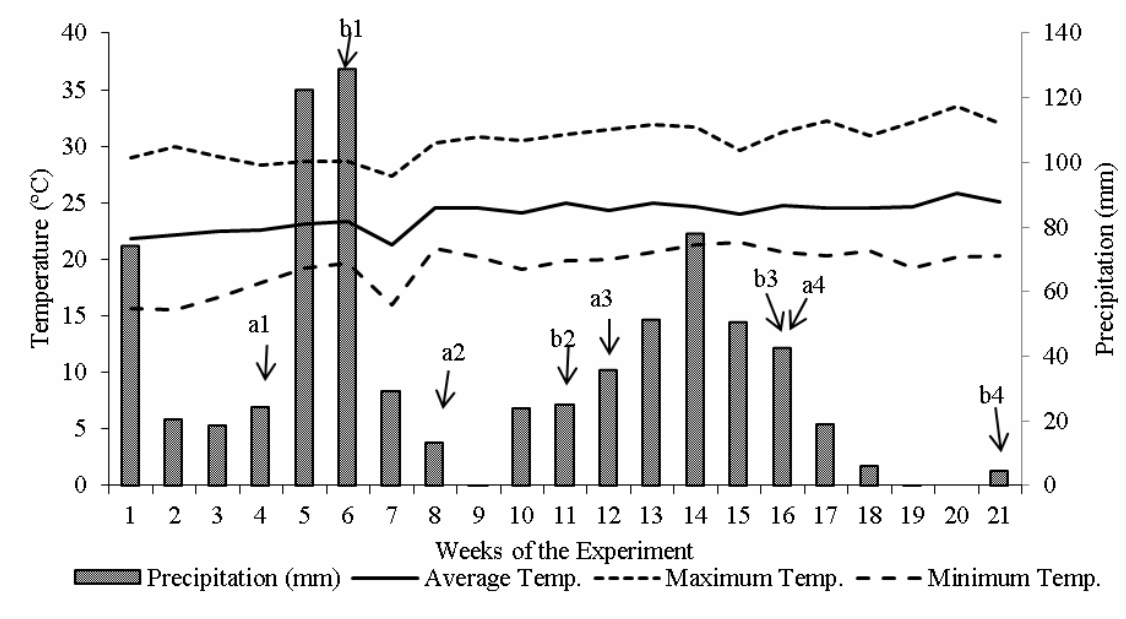

a: 1 st, 2 nd, 3rd and 4 th cut at $28 \mathrm{~d}$

b: 1 st, 2 nd, 3 rd and 4 th cut at $35 \mathrm{~d}$ regrowth interval

Source: UNIOESTE, adapted by author.

Plots with a regrowth interval of $28 \mathrm{~d}$ were cut on November 26 and December 26, 2010, and January 21 and February 18, 2011. Plots with a regrowth interval of $35 \mathrm{~d}$ were cut on December 6, 2010, and January 10, February 14, and March 21, 2011. Within five $d$ after the initial and subsequent cuts, the plots were fertilized with urea. Three robust tillers were also selected and scored in each plot.

- After each cut, the following characteristics were evaluated: LAR, phyllochron (Phy), LER, plant height $(\mathrm{PH})$, leaf stem ratio (LSR), tiller mass (TM), stem length (SL), stem diameter (SD), average leaf length (LL), tiller number per square meter (TN), and DM yield.

The LAR, LER, and LL were obtained by measuring the sheets every four $d$ during the experimental period and Phy was calculated from the LAR. PH was measured in millimeters with a ruler before every cut and LSR was measured from 30 tillers that were separated into leaf blade and stem after cutting and then dried in an oven with forced air circulation at $55{ }^{\circ} \mathrm{C}$ for 72 hours. The LSR was calculated from the ratio between the dry weight of the leaves and the dry weight of the stems. SL was measured in millimeters with a ruler from the same 30 tillers used for LSR, and SD was measured with calipers. DM yield was calculated from a random $50 \mathrm{~cm} \times 50 \mathrm{~cm}$ area $\left(0.25 \mathrm{~m}^{2}\right)$ within each experimental plot. After cutting, the forage was placed in bags, transported to the laboratory, and immediately weighed and dried at $55{ }^{\circ} \mathrm{C}$ for 72 hours. Samples were weighed again to calculate DM yield ha-1. TN per square meter was calculated by multiplying the fresh mass of each $0.25 \mathrm{~m}^{2}$ area by four and dividing by the average weight of each tiller from the same area.

After drying, the samples were ground in a Willey mill with a 30 mesh sieve and stored in labeled plastic bags prior to bromatological analysis of dry matter (DM), mineral matter (MM), NDF, acid detergent fiber (ADF), CP, lignin (LIG), cellulose (CEL) and hemicellulose (HEM), following the methods of Silva and Queiroz (2009).

Data were evaluated with an analysis of variance, and the effect of regrowth interval was assessed with a Tukey test, while $\mathrm{N}$ application was examined with regression analysis. The choice of models was based on the coefficients of determination $\left(\mathrm{R}^{2}\right)$ and the significance (at a 5\% level) of the partial regression coefficients was calculated with a Student's t-test. The significance of the factors included in the initial statistical model was respected. All analyses were conducted in the statistical program Sisvar (FERREIRA, 2011). 


\section{Results and Discussion}

There were significant differences $(p<0.05)$ between regrowth intervals for canopy height $(\mathrm{PH})$, DM yield (DMY), average mass per tiller (TM),
LSR, SL, SD, LL, LAR, Phy, LER, and TN (Table 1). There was no interaction between $\mathrm{N}$ and interval in the variables listed, except in the 3 rd cut, at 28 $\mathrm{d}\left(\hat{\mathrm{Y}}=17.20+0.0045875 * \mathrm{X}, \mathrm{CV}=17.19 \%, \mathrm{R}^{2}=\right.$ $65.88 \%)$.

Table 1. Height of plants, dry matter yield (DMY), average tiller mass (TM), leaf stem ratio (LSR), stem length (SL), stem diameter (SD), size of leaves (LL), leaf appearance rate (LAR), phyllochron (Phy), leaf elongation rate (LER), and tiller number $(\mathrm{TN})$ at the regrowth ages on the day of cutting.

\begin{tabular}{|c|c|c|c|c|c|c|c|c|c|c|c|}
\hline $\begin{array}{l}\text { Regrowth } \\
\text { age }\end{array}$ & $\begin{array}{l}\text { Height } \\
(\mathrm{cm})\end{array}$ & $\begin{array}{c}\text { DMY } \\
\left(\mathrm{kg} \mathrm{ha}^{-1}\right)\end{array}$ & $\begin{array}{l}\mathrm{TM} \\
(\mathrm{g})\end{array}$ & LSR & $\begin{array}{l}\mathrm{SL} \\
(\mathrm{cm})\end{array}$ & $\begin{array}{l}\text { SD } \\
(\mathrm{mm})\end{array}$ & $\begin{array}{l}\mathrm{LL} \\
(\mathrm{cm})\end{array}$ & LAR & Phy & $\begin{array}{c}\text { LER } \\
\left(\mathrm{mm} \mathrm{day}^{-1}\right)\end{array}$ & $\begin{array}{c}\mathrm{TN} \\
\left(\mathrm{m}^{-2}\right)\end{array}$ \\
\hline \multicolumn{12}{|c|}{ 1st Cut } \\
\hline $28 \mathrm{~d}$ & $20.50 \mathrm{~b}$ & $3904.7 \mathrm{~b}$ & $0.18 \mathrm{~b}$ & $1.16 \mathrm{a}$ & $11.12 \mathrm{~b}$ & $1.67 \mathrm{a}$ & $9.45 \mathrm{a}$ & $0.32 \mathrm{a}$ & $3.70 \mathrm{~b}$ & $9.30 \mathrm{a}$ & $3846 \mathrm{a}$ \\
\hline $35 \mathrm{~d}$ & $45.80 \mathrm{a}$ & $4940.7 \mathrm{a}$ & $0.46 \mathrm{a}$ & $1.10 \mathrm{a}$ & $22.16 \mathrm{a}$ & $1.61 \mathrm{a}$ & $10.10 \mathrm{a}$ & $0.29 \mathrm{~b}$ & $4.21 \mathrm{a}$ & $9.00 \mathrm{a}$ & $2667 \mathrm{~b}$ \\
\hline CV (\%) & 15.60 & 15.51 & 25.99 & 21.35 & 13.11 & 11.93 & 10.89 & 10.86 & 9.96 & 12.20 & 20.08 \\
\hline \multicolumn{12}{|c|}{ 2nd Cut } \\
\hline $28 \mathrm{~d}$ & $46.60 \mathrm{a}$ & $5590.8 \mathrm{a}$ & $0.16 \mathrm{~b}$ & $1.02 \mathrm{~b}$ & $20.87 \mathrm{a}$ & $1.42 \mathrm{~b}$ & $14.65 \mathrm{~b}$ & $0.28 \mathrm{a}$ & $4.23 \mathrm{~b}$ & $17.10 \mathrm{a}$ & $3652 \mathrm{a}$ \\
\hline $35 \mathrm{~d}$ & $26.28 \mathrm{~b}$ & 2919.7 b & $0.21 \mathrm{a}$ & $1.41 \mathrm{a}$ & $13.60 \mathrm{~b}$ & $1.84 \mathrm{a}$ & $15.90 \mathrm{a}$ & $0.28 \mathrm{a}$ & $4.77 \mathrm{a}$ & $15.10 \mathrm{~b}$ & $1253 \mathrm{~b}$ \\
\hline CV (\%) & 10.29 & 15.11 & 31.89 & 17.26 & 17.19 & 12.50 & 9.89 & 12.20 & 11.64 & 13.43 & 16.55 \\
\hline \multicolumn{12}{|c|}{ 3rd Cut } \\
\hline $28 \mathrm{~d}$ & $26.05 \mathrm{~b}$ & $3336.1 \mathrm{~b}$ & $0.15 \mathrm{~b}$ & $1.56 \mathrm{a}$ & $11.66 \mathrm{~b}$ & $1.50 \mathrm{a}$ & $15.15 \mathrm{~b}$ & $0.30 \mathrm{a}$ & $3.93 \mathrm{a}$ & $16.10 \mathrm{a}$ & $2525 \mathrm{a}$ \\
\hline $35 \mathrm{~d}$ & $36.88 \mathrm{a}$ & $4070.8 \mathrm{a}$ & $0.23 \mathrm{a}$ & $1.14 \mathrm{~b}$ & $21.48 \mathrm{a}$ & $1.54 \mathrm{a}$ & $16.4 \mathrm{a}$ & $0.31 \mathrm{a}$ & $3.67 \mathrm{a}$ & $17.00 \mathrm{a}$ & $2049 \mathrm{~b}$ \\
\hline CV (\%) & 11.83 & 16.02 & 29.39 & 9.14 & 15.65 & 10.45 & 8.62 & 11.50 & 14.71 & 13.07 & 26.86 \\
\hline \multicolumn{12}{|c|}{ 4th Cut } \\
\hline $28 \mathrm{~d}$ & $29.75 \mathrm{a}$ & $2995.0 \mathrm{a}$ & $0.24 \mathrm{a}$ & $1.27 \mathrm{~b}$ & $18.48 \mathrm{a}$ & $1.70 \mathrm{a}$ & $17.05 \mathrm{a}$ & $0.35 \mathrm{a}$ & $3.28 \mathrm{~b}$ & $19.8 \mathrm{a}$ & $14.39 \mathrm{~b}$ \\
\hline $35 \mathrm{~d}$ & $16.14 \mathrm{~b}$ & $2383.6 \mathrm{~b}$ & $0.13 \mathrm{~b}$ & $1.62 \mathrm{a}$ & $8.92 \mathrm{~b}$ & $1.35 \mathrm{~b}$ & $14.00 \mathrm{~b}$ & $0.31 \mathrm{~b}$ & $3.99 \mathrm{a}$ & $13.50 \mathrm{~b}$ & $2036 \mathrm{a}$ \\
\hline CV (\%) & 8.67 & 11.71 & 30.27 & 12.82 & 11.39 & 9.38 & 11.37 & 15.17 & 10.71 & 16.32 & 3.20 \\
\hline
\end{tabular}

Values followed by the same letter in each column and cut do not differ at $5 \%$ probability with Tukey's test.

The canopy height, DMY, and SL were significantly higher $(p<0.05)$ at $35 \mathrm{~d}$ of regrowth on the 1 st and $3 \mathrm{rd}$ cuts and at $28 \mathrm{~d}$ on the 2 nd and 4 th cuts (Table 1). It is likely that the low rainfall of $195.4 \mathrm{~mm}$ between the 6th to the 10th week of the experiment against $293.2 \mathrm{~mm}$ from 5 th to 8 th week of the experiment (Figure 1) reduced canopy height, DMY, and shorter SL for the 2nd cut at 35 d (10 weeks) compared to the 2 nd cut at $28 \mathrm{~d}$ ( 8 weeks), respectively. In the 4 th cut, a similar pattern was observed, with lower rainfall during the 16th to 21 th weeks $(46.0 \mathrm{~mm})$ than during the 13 th to 16 th weeks (225.0 mm) (Figure 1).

$\mathrm{N}$ application affected canopy height in each cut except the 3rd (Figure 2). There was a linear effect on the 1 st and 4 th cuts and a quadratic effect on the 2 nd cut. Oliveira et al. (2010) reported greater canopy height as a function of $\mathrm{N}$ fertilizer on Tifton 85 , which varied as a function of $\mathrm{N}$ levels and rainfall. Quaresma et al. (2011) found an average increase of $0.052 \mathrm{~cm}$ in Tifton 85 for each $\mathrm{kg} \mathrm{N}$ ha $^{-1}$ applied every $30 \mathrm{~d}$ over a $120 \mathrm{~d}$ period, a value similar that seen from the 4 th cut of this experiment. $\mathrm{N}$ fertilization linearly increased the DMY on the 1 st and 4th cuts (Figure 3), consistent with previous findings (OLIVEIRA et al., 2010; QUARESMA et al., 2011). The highest average DMY in the four cuts was observed with $400 \mathrm{~kg} \mathrm{~N} \mathrm{ha}^{-1}$ at $28 \mathrm{~d}$ of regrowth, and the lowest was observed with no added $\mathrm{N}$ at $35 \mathrm{~d}$ of regrowth (Table 1). The average total DMY was $3956.71 \mathrm{~kg} \mathrm{ha}^{-1}$ at $28 \mathrm{~d}$ of regrowth and 3578.75 $\mathrm{kg} \mathrm{ha}^{-1}$ at $35 \mathrm{~d}$ of regrowth. These differences are 
attributable to the distribution of rainfall during the $\mathrm{mm}$ ) compared to the $35-\mathrm{d}$ interval (388 $\mathrm{mm}, 92$ 28-d interval (137 mm, $293 \mathrm{~mm}, 85.4 \mathrm{~mm}$, and $222 \mathrm{~mm}, 257.8 \mathrm{~mm}$, and $30 \mathrm{~mm}$ ) (Figure 1).

Figure 2. Canopy height as a function of nitrogen applied after each cut of Tifton 85.

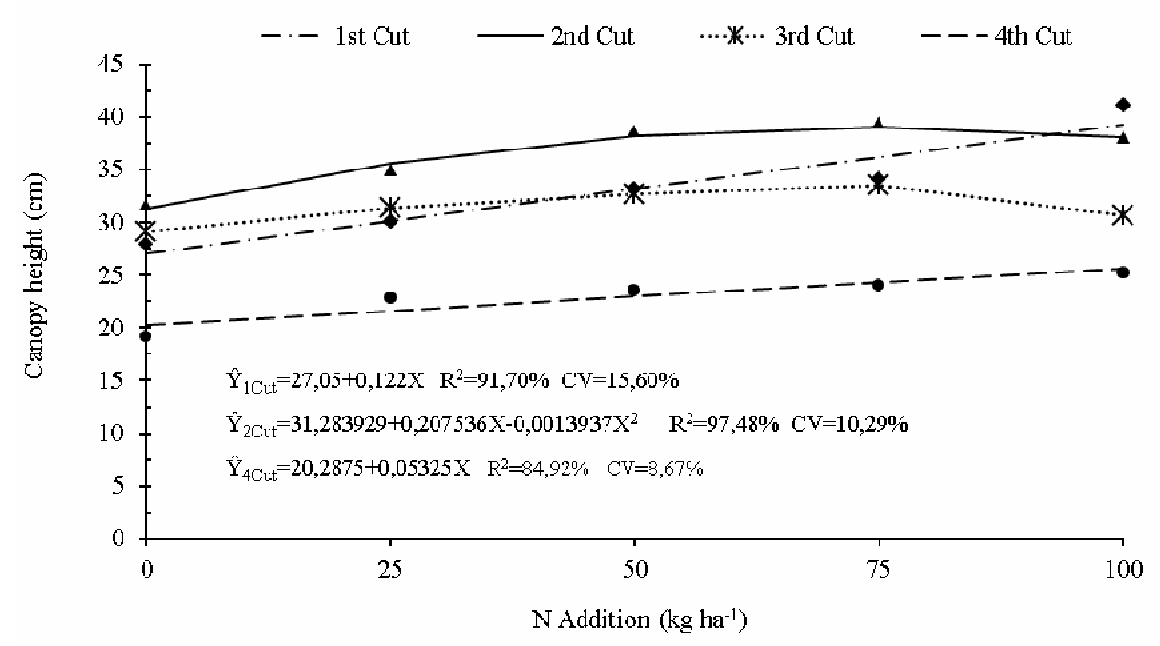

Figure 3. Effect of nitrogen on the dry matter yield (DMY) ha-1 in each cut of Tifton 85 .

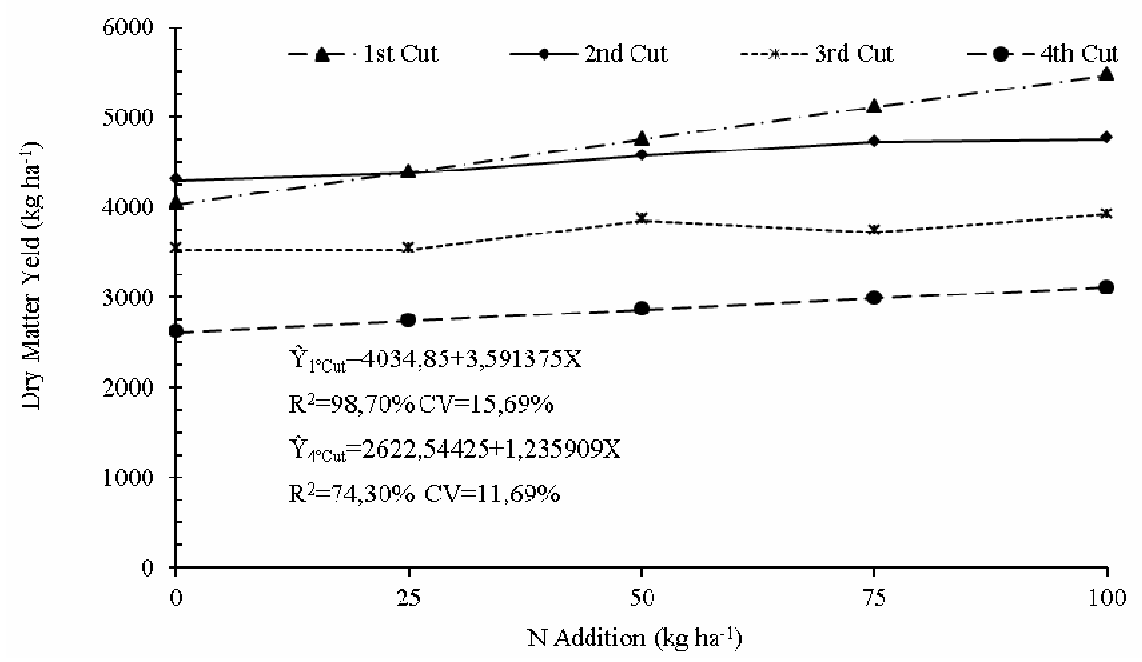

Total DM production $\left(\mathrm{kg} \mathrm{ha}^{-1}\right)$ was 14675,15 066, 16197,16246 , and 16949 for the 28-d interval and 12 490, 13 870, 14 105, 15 432, and 15678 for the 35-d interval at doses of 0, 100, 200, 300, and $400 \mathrm{~kg} \mathrm{ha}^{-1} \mathrm{~N}$, respectively. The corresponding $\mathrm{N}$ use efficiency values were 3.91, 7.61, 5.24, and 5.68 $\mathrm{kg} \mathrm{DM} \mathrm{kg}{ }^{-1} \mathrm{~N}$ for the 28-d interval and 13.80, 8.07, 9.81, and $7.97 \mathrm{~kg} \mathrm{DM} \mathrm{kg}^{-1} \mathrm{~N}$ for the $35-\mathrm{d}$ interval, respectively, with $100,200,300$, and $400 \mathrm{~kg} \mathrm{ha}^{-1}$ of
$\mathrm{N}$. The highest $\mathrm{N}$ use efficiency occurred with 100 and $200 \mathrm{~kg} \mathrm{~N} \mathrm{ha}^{-1}$, possibly owing to an increased $\mathrm{N}$ use efficiency $30 \mathrm{~d}$ after $\mathrm{N}$ application between 150 and $300 \mathrm{~kg} \mathrm{ha}^{-1}$ (OLIVEIRA et al., 2010). Quaresma et al. (2011) reported N use efficiency of $22.67 \mathrm{~kg} \mathrm{DM} \mathrm{kg}^{-1}$ of applied $\mathrm{N}$ in a very fertile soil, and Rocha et al. (2000) reported $\mathrm{N}$ use efficiency of $10.30,8.05$, and $5.15 \mathrm{~kg}$ DM with $\mathrm{N}$ applications of 100,200 , and $400 \mathrm{~kg} \mathrm{ha}^{-1}$, respectively. 
The average mass of each tiller in the first three cuts was significantly higher $(p<0.05)$ at $35 \mathrm{~d}$ of regrowth and in the 4 th cut at $28 \mathrm{~d}$ of regrowth (Table 1). The other cuts at both intervals might have had lower average mass per tiller because they had higher DMY. Premazzi et al. (2003) reported an inverse relationship between $\mathrm{TN}$ and mass, as greater numbers of taller tillers compete to assimilate nutrients, thereby reducing individual tiller mass; increasing $\mathrm{N}$ availability may lead to taller tillers. There was no significant variation in $\mathrm{TN}$ with respect to cutting interval and $\mathrm{N}$ level (Figure 4). There was no effect of $\mathrm{N}$ application ( $p>$ 0.05 ) on TM (Figure 5), nor on LSR (Figure 6). TN and TM determine forage productivity (MOREIRA et al., 2015), and this is evident in the higher TN and lower TM in the 2nd cut of the 28-d interval, which had a greater DMY.

Figure 4. Effect of nitrogen application on the tiller number $\mathrm{m}^{-2}$ in each cut of Tifton 85 .

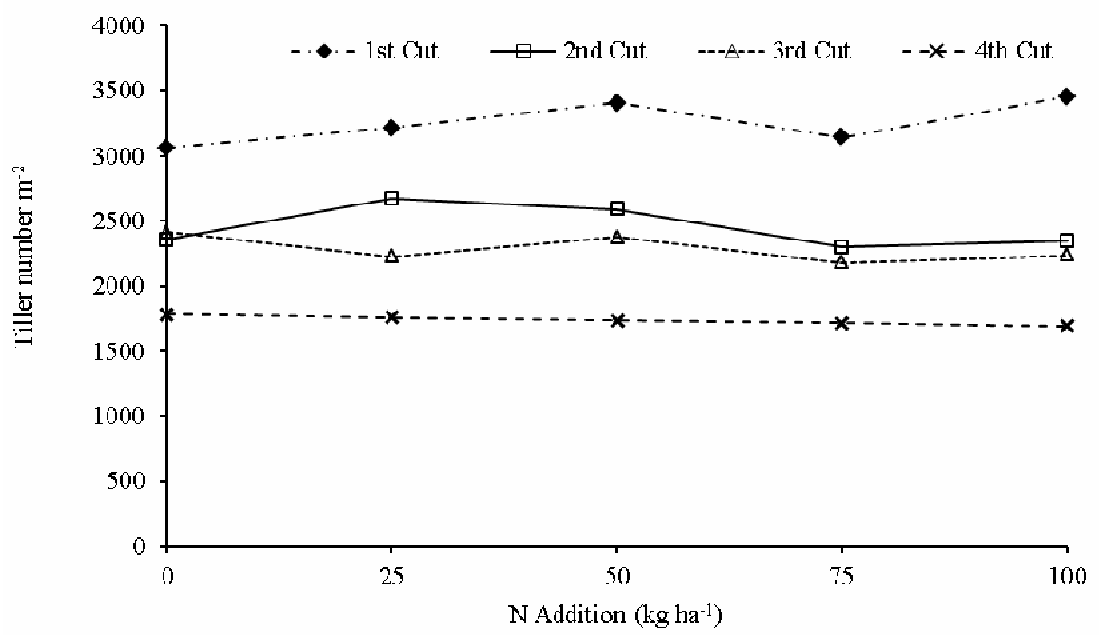

LSR did not differ between intervals in the 1 st cut, but it was significantly higher $(p<0.05)$ at 35 $\mathrm{d}$ in the 2 nd and 4 th cuts and at $28 \mathrm{~d}$ in the 3 rd cut (Table 1). When height and DMY are greater, LSR is smaller, but this was not observed in the 4th cut. Dittrich et al. (2005) found LSRs of 1.79 and 1.75 for Tifton 85 plants that were 12 and $25 \mathrm{~cm}$ tall. A LSR of approximately 1.2 contains about two thirds of total DM is available in leafs. As tillers age, LSR decreases owing to stem elongation; the stem has a higher fiber content and less protein (CUTRIM JUNIOR et al., 2014; MARCHESAN et al., 2013). However, LSR also varies with the season (MOREIRA et al., 2015). In general, as $\mathrm{N}$ application increased, the stem length also increased (Figure 7), although only the 2nd and 4th cuts were significantly higher $(p<0.05)$, with similar results at canopy height.

SD was significantly greater $(p<0.05)$ in the 2 nd cut at the 35-d interval and in the 4 th cut at the $28-d$ interval (Table 1). In the 4th cut, the difference was likely due to less rainfall during the $35 \mathrm{~d}$ growing period (Figure 1, Table 1). Larger diameter stems retain more water, so forage cut for hay takes longer to dry. There was no significant difference $(p>0.05)$ in SD between regrowth intervals in the 1 st and $3 \mathrm{rd}$ cuts. The LL leaves were larger $(p<0.05)$ at $35 \mathrm{~d}$ in the 2 nd and 3 rd cuts and at $28 \mathrm{~d}$ in the 4 th cut. Leaf size was smaller and not significantly different $(p>0.05)$ in the first cut, probably owing to rapid tiller growth after $\mathrm{N}$ application. Neres et al. (2012) found that Tifton 85 leaves were, on average, 20.15, 22.76 , and $20.49 \mathrm{~cm}$ without $\mathrm{N}$ at the $1 \mathrm{st}, 2 \mathrm{nd}$, and 3 rd cuts, and 15.08, 21.25, and $16.55 \mathrm{~cm}$ with 150 $\mathrm{kg} \mathrm{ha}^{-1}$ of $\mathrm{N}$ applied three times, respectively. $\mathrm{N}$ was positively correlated with LL $(p<0.05)$ in the 1 st, 2nd, and 4th cuts (Figure 8). Premazzi et al. (2011) found an increased LL and LER in treatments with no added $\mathrm{N}$ and with $80 \mathrm{mg} \mathrm{N} \mathrm{kg}^{-1}$ of soil compared to applications of 160 and $240 \mathrm{mg} \mathrm{N} \mathrm{kg}^{-1}$ of soil. 
Figure 5. Effect of nitrogen doses on the average tiller mass in the four cuts of Tifton 85 .

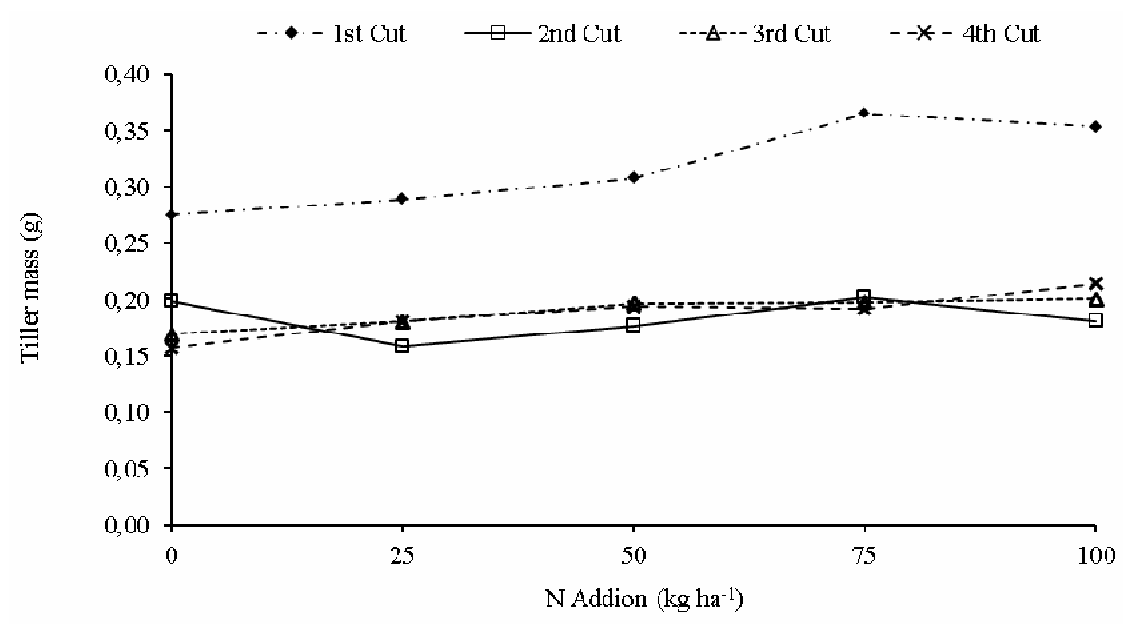

Figure 6. Effect of nitrogen on the leaf stem ratio (LSR) in the four cuts of Tifton 85.

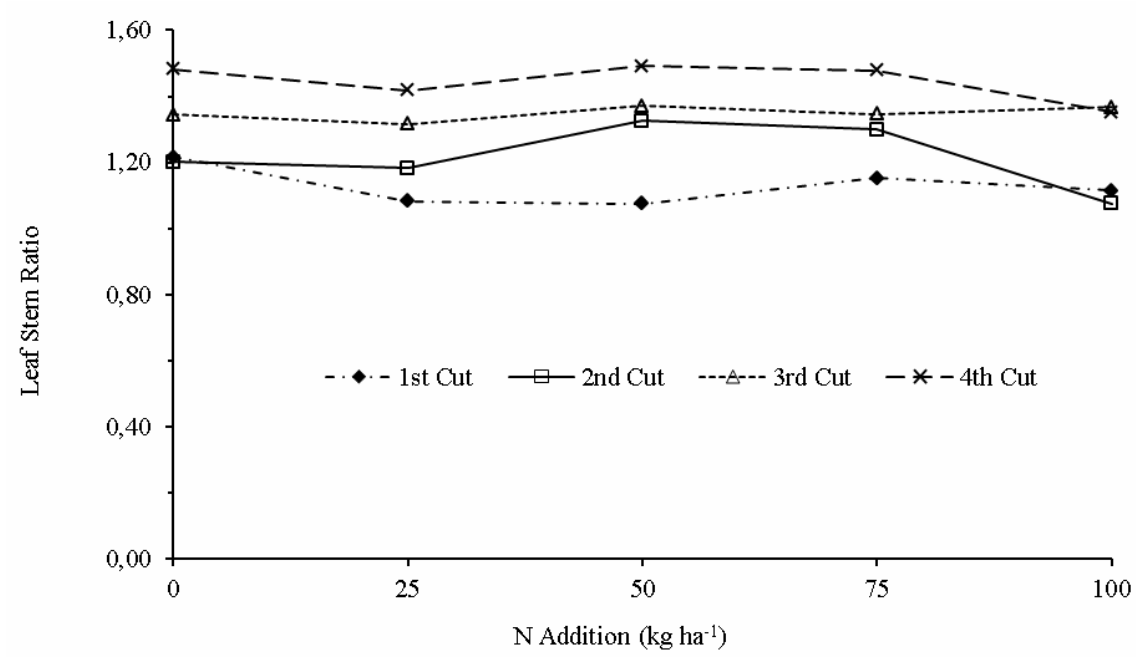

Figure 7. Effect of nitrogen on the average stem length (SL) in the four cuts of Tifton 85.

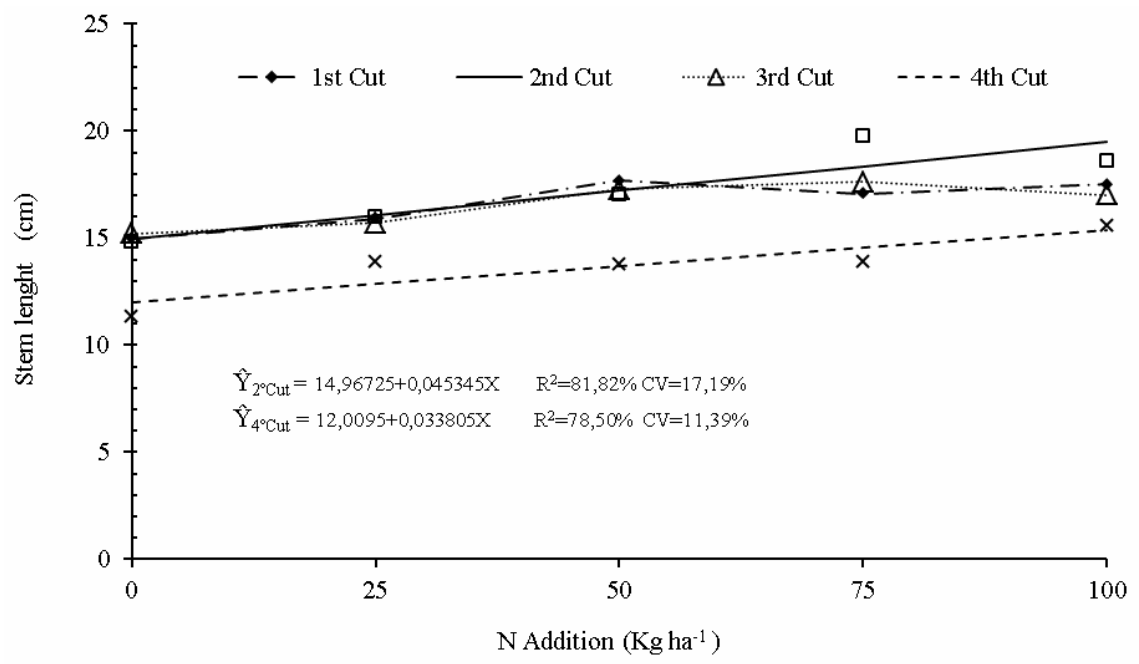


Figure 8. Leaf length (LL) as a function of nitrogen in the four cuts of Tifton 85.

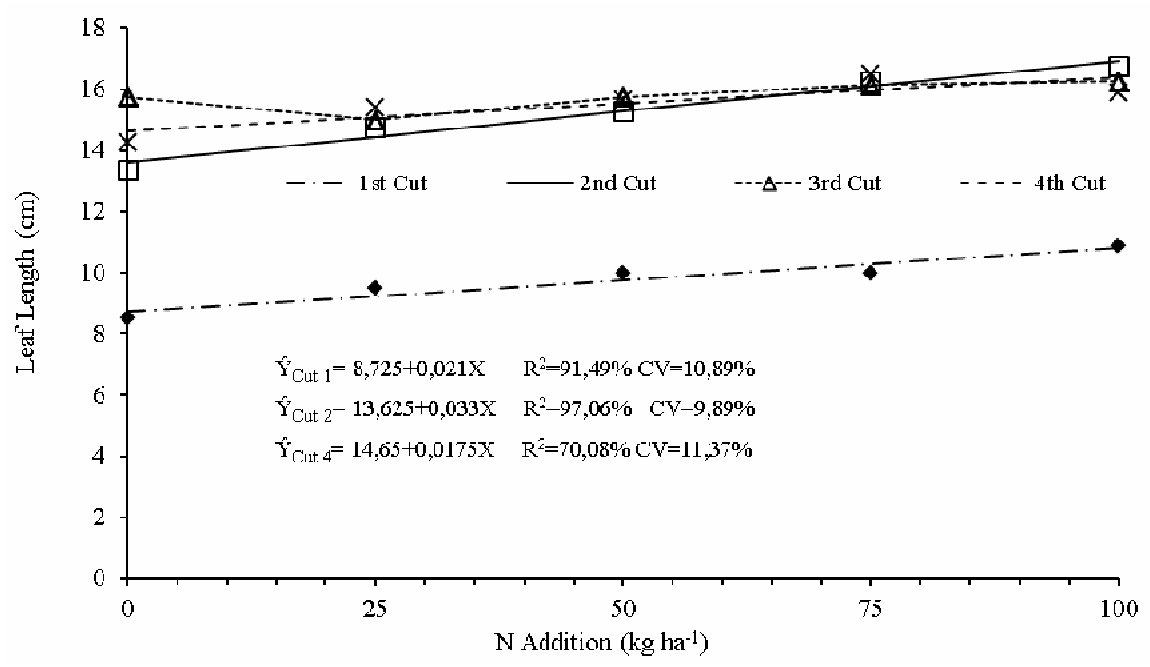

LAR is the average number of leaves that appeared per tiller per day or degree days (PEREIRA et al., 2011; MACHADO et al., 2013). LAR was higher $(p<0.05)$ in the 1 st and 4 th cut at the 28 -d interval and there was no difference in the 2 nd and 3rd cuts (Table 1). $\mathrm{N}$ application did not influence LAR ( $p>0.05$; Figure 9). However, Pereira et al. (2011) reported that LAR in Tifton 85 grass increased from 0.0024 and 0.0023 leaves per tiller per day for each increase of $1 \mathrm{~kg}$ of $\mathrm{N}$ applied in the first and second year, respectively. $\mathrm{N}$ is required for cell division and elongation in the tiller meristematic zone and therefore, in most cases, LAR increases with increasing N. Phy is the time interval between the appearance of two successive leaves and is the inverse of LAR (PACIULLO et al., 2005; PEREIRA et al., 2011; MACHADO et al., 2013).

Figure 9. Leaf appearance rate (LAR) as a function of nitrogen in the four cuts of Tifton 85 .

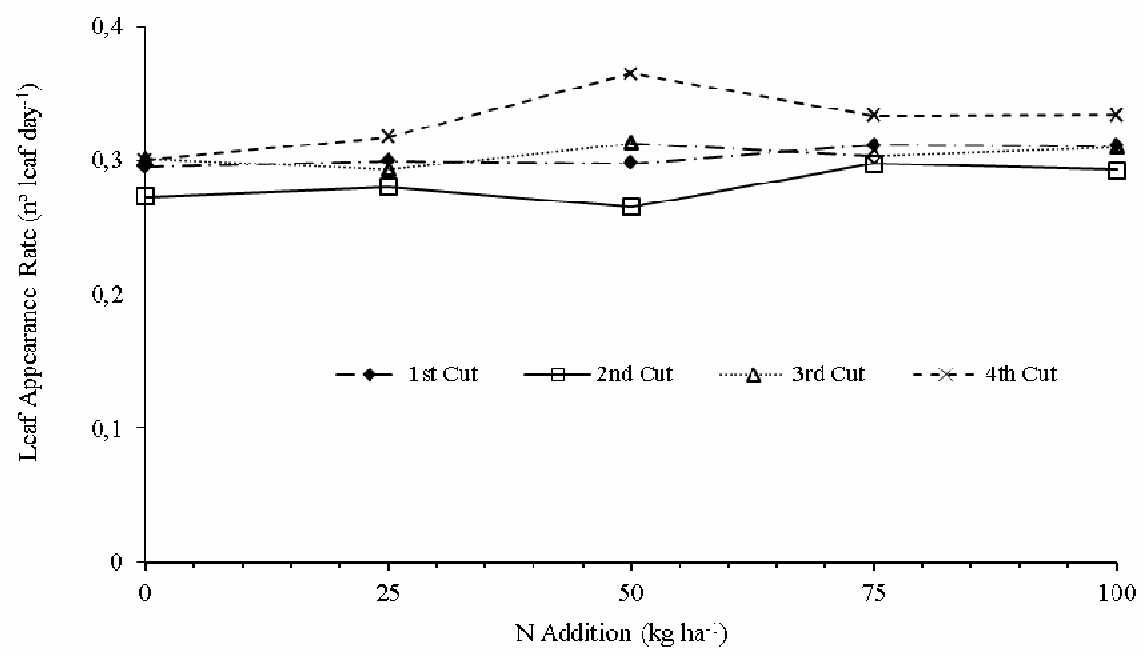

Phy was higher $(p<0.05)$ for the 35-d interval in the 1st, 2nd, and 4th cuts, and there was no difference in the $3 \mathrm{rd}$ cut compared to $28 \mathrm{~d}$ interval (Table 1). $\mathrm{N}$ application had no significant effect on
Phy ( $p>0.05$; Figure 10). In contrast, Pereira et al. (2011) found that Phy decreased between 0.015 and 0.010 unit for each $\mathrm{kg}$ of $\mathrm{N}$ applied ff a study that lasted two years. The same authors found that Phy 
increased between 0.04 and $0.01 \mathrm{~d}$ in the first and second year for every increment of $1 \mathrm{~cm}$ in plant height at cutting time LER reflects daily growth. There was no difference in LER in the 1st and 3rd cuts, while it was higher $(p<0.05)$ in the 2 nd and 4 th cuts for the 28-d interval (Table 1). $\mathrm{N}$ application significantly influenced cuts 1 and 2 (Figure 11). Differences in weather affected LAR, Phy, and LER (Figure 1). Pereira et al. (2011) found a consistent increase in LAR, Phy, and LER in response to $\mathrm{N}$ fertilization in Tifton 85.

A greater $(p<0.05)$ TN per square meter (Table 1) was found in the 1 st cut in at the 28 -d interval $\left(3846 \mathrm{~m}^{-2}\right)$, with fewer in the second cut at the 35-d interval $\left(1253 \mathrm{~m}^{-2}\right)$. TN was greater $(p<0.05)$ only in the 4 th cut at the 35-d interval. $\mathrm{N}$ levels at the start of the regrowth interval tend to increase tiller number, which is then reduced owing to shading from a tall canopy. Plant height was greatest in the
1 st cut at $35 \mathrm{~d}$ of regrowth, an interval with abundant precipitation $(388 \mathrm{~mm})$. However, self-shading from a tall canopy increases tiller senescence (ALDERMAN et al., 2011), so fewer tillers were present in the 2nd cut at the 35-d interval, which also had less precipitation $(92 \mathrm{~mm})$. Moreira et al. (2015) reported the following average TN per square meter in the specified months and with different $\mathrm{N}$ applications ( $\mathrm{kg} \mathrm{ha}^{-1}$ ): 2340 (December 2008, 0), 2440 (January 2009, 100), 2329 (February 2009, 200), and 2265 (March 2009, 400) and the highest number of total tillers occurred with an application of $227 \mathrm{~kg} \mathrm{ha}^{-1}$ of N. Vilela et al. (2005) stated that at a height of $20 \mathrm{~cm}$, grass may reduce the incidence of solar radiation at the tiller base, thereby reducing tiller number. This effect might explain the reduction in tiller number in the 2 nd cut of the present study, after a period associated with higher rates of daily leaf elongation.

Figure 10. Effect of nitrogen on the phyllochron (Phy) in four cuts of Tifton 85.

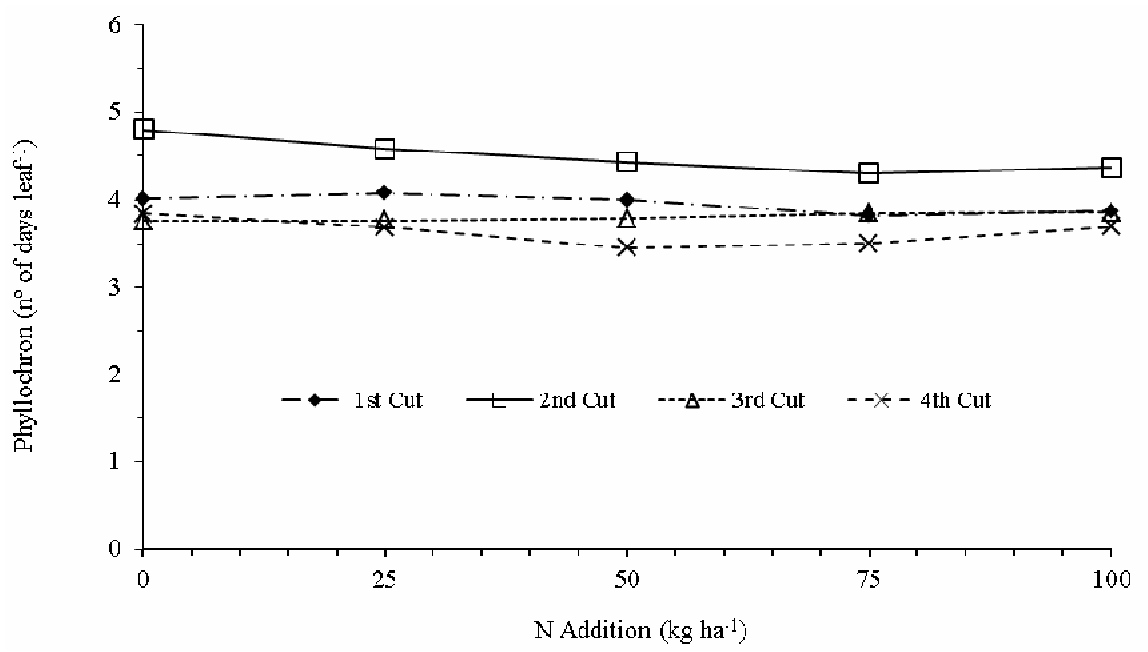

There was a significant effect $(p<0.05)$ of interval for DM, NDF, CP, LIG, and CEL (Table 2) and of $\mathrm{N}$ in ADF and $\mathrm{CP}$ (Figures 3 and 4). There was no interaction $(p>0.05)$ between $\mathrm{N}$ levels and interval for these factors. The DM content in all cuts at the 35-d interval was higher $(p<0.05)$ than in the 28-d interval (Table 2). A lower content (196.7 $\mathrm{g} \mathrm{kg}^{-1}$ ) was recorded from the first cut at $28 \mathrm{~d}$. MM content was not significant different among cuts or regrowth intervals (Table 2 ). The amount varied between 72.8 and $77.8 \mathrm{~g} \mathrm{~kg}^{-1} \mathrm{DM}$ and was lower than those reported by Aguiar et al. (2006) from tropical grasses (pearl millet Bulk-1 and Sudanense S-4202, elephant Cameroon, sorghum SF-25 and API-467-4-2, 84.5-111.4 $\left.\mathrm{g} \mathrm{kg}^{-1} \mathrm{DM}\right)$, but was similar to those found by Ribeiro et al. (2001) from Tifton 85 with regrowth intervals of $28,35,42$, and $56 \mathrm{~d}$, and higher than that $\left(61.2 \mathrm{~g} \mathrm{~kg}^{-1} \mathrm{DM}\right)$ reported by Silva et al. (2007) at Tifton 85 hay. $\mathrm{N}$ did not influence MM content. 
Figure 11. Effect of nitrogen on the daily leaf elongation rate (LER) in four cuts Tifton 85.

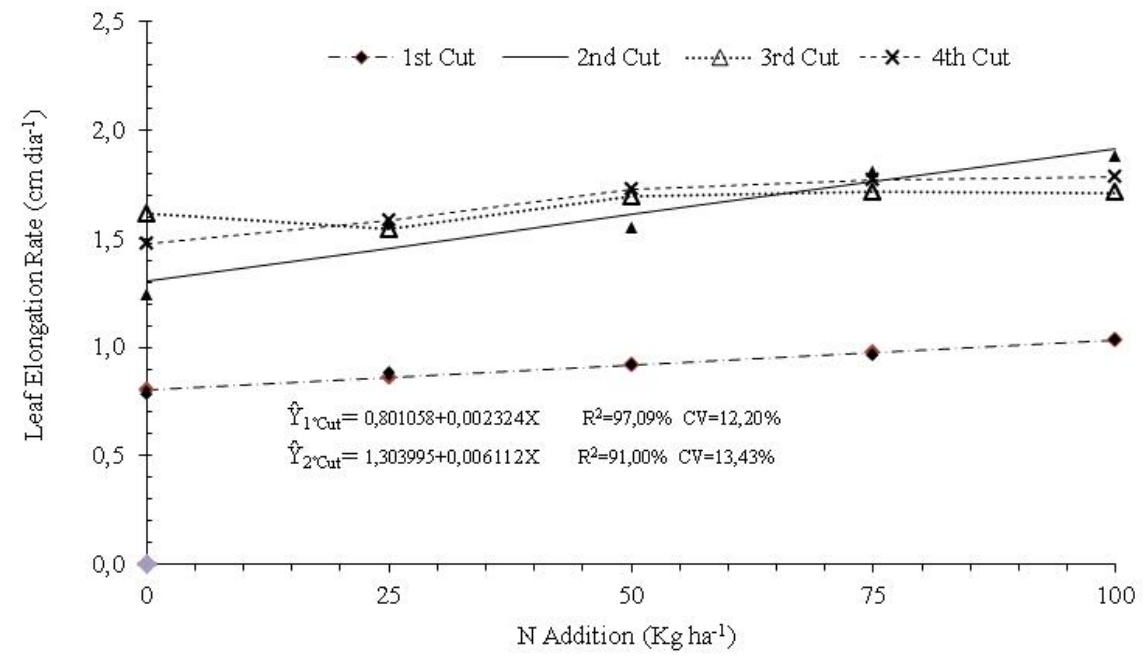

Table 2. Contents $\left(\mathrm{g} \mathrm{kg}^{-1}\right)$ of dry matter (DM), mineral matter (MM), neutral detergent fiber (NDF), acid detergent fiber (ADF), crude protein (CP), lignin (LIG) cellulose (CEL), hemicellulose (HEM), and in vitro digestibility of dry matter (IVDDM) in Tifton 85 at fresh forage harvested at 28 and 35 days of regrowth.

\begin{tabular}{lccccccccc}
\hline Regrowth age & DM & MM & NDF & ADF & CP & LIG & CEL & HEM & IVDDM \\
\hline 28 days & $196.7 \mathrm{~b}$ & $77.8 \mathrm{a}$ & $777.2 \mathrm{a}$ & $427.6 \mathrm{a}$ & $185.4 \mathrm{a}$ & $137.2 \mathrm{a}$ & $278.3 \mathrm{~b}$ & $349.5 \mathrm{a}$ & $522.6 \mathrm{~b}$ \\
35 days & $225.3 \mathrm{a}$ & $75.6 \mathrm{a}$ & $787.3 \mathrm{a}$ & $463.1 \mathrm{a}$ & $158.9 \mathrm{~b}$ & $150.7 \mathrm{a}$ & $318.5 \mathrm{a}$ & $324.3 \mathrm{a}$ & $558.1 \mathrm{a}$ \\
CV $(\%)$ & 7.56 & 10.63 & 5.50 & 19.19 & 15.02 & 50.83 & 14.35 & 27.97 & 9.36 \\
& & & & & 2 nd Cut & & & & \\
28 days & $216.2 \mathrm{~b}$ & $74.8 \mathrm{a}$ & $827.5 \mathrm{a}$ & $493.2 \mathrm{a}$ & $140.1 \mathrm{a}$ & $147.1 \mathrm{a}$ & $352.5 \mathrm{a}$ & $334.3 \mathrm{a}$ & $480.2 \mathrm{~b}$ \\
35 days & $262.9 \mathrm{a}$ & $72.8 \mathrm{a}$ & $839.9 \mathrm{a}$ & $521.0 \mathrm{a}$ & $146.4 \mathrm{a}$ & $159.3 \mathrm{a}$ & $342.9 \mathrm{a}$ & $318.8 \mathrm{a}$ & $529.2 \mathrm{a}$ \\
CV $(\%)$ & 6.36 & 10.08 & 5.51 & 10.47 & 9.22 & 31.30 & 14.45 & 22.41 & 19.40 \\
& & & & & $3 \mathrm{rd} \mathrm{Cut}$ & & & & \\
28 days & $268.6 \mathrm{a}$ & $74.6 \mathrm{a}$ & $786.2 \mathrm{a}$ & $411.9 \mathrm{a}$ & $169.7 \mathrm{a}$ & $71.8 \mathrm{a}$ & $339.9 \mathrm{a}$ & $374.4 \mathrm{a}$ & $584.3 \mathrm{a}$ \\
35 days & $248.6 \mathrm{~b}$ & $78.7 \mathrm{a}$ & $785.0 \mathrm{a}$ & $406.5 \mathrm{a}$ & $159.3 \mathrm{~b}$ & $75.8 \mathrm{a}$ & $337.5 \mathrm{a}$ & $378.5 \mathrm{a}$ & $594.2 \mathrm{a}$ \\
CV (\%) & 4.25 & 10.42 & 5.03 & 13.730 & 7.60 & 38.99 & 12.24 & 12.61 & 9.01 \\
& & & & & 4 th Cut & & & & \\
28 days & $234.4 \mathrm{~b}$ & $74.7 \mathrm{a}$ & $757.3 \mathrm{a}$ & $457.4 \mathrm{a}$ & $208.2 \mathrm{a}$ & $61.2 \mathrm{~b}$ & $382.7 \mathrm{a}$ & $300.0 \mathrm{a}$ & $582.5 \mathrm{a}$ \\
35 days & $321.8 \mathrm{a}$ & $74.7 \mathrm{a}$ & $709.8 \mathrm{~b}$ & $443.1 \mathrm{a}$ & $193.2 \mathrm{~b}$ & $88.8 \mathrm{a}$ & $336.8 \mathrm{~b}$ & $266.8 \mathrm{a}$ & $588.5 \mathrm{a}$ \\
CV (\%) & 3.63 & 15.90 & 5.44 & 12.73 & 9.40 & 34.12 & 10.11 & 23.68 & 8.41 \\
\hline
\end{tabular}

Values followed by the same letter in each column and in each cut do not differ at $5 \%$ probability with Tukey's test.

The NDF content (Table 2) varied between 709.9 and $839.9 \mathrm{~g} \mathrm{~kg}^{-1} \mathrm{DM}$ in the four cuts and intervals, with no difference between intervals in the 1 st, 2 nd and 3rd cuts; in the 4th cut, the NDF content was higher $(p<0.05)$ at the 28-d interval $\left(757.3 \mathrm{~g} \mathrm{~kg}^{-1}\right.$ DM) than at the 35 -d interval $\left(709.9 \mathrm{~g} \mathrm{~kg}^{-1} \mathrm{DM}\right)$, that is justified by the smaller LSR and greatest content of cellulose and hemicellulose (Table 2). The contents, which were relatively high, exceeded those found by Fontaneli et al. (2004) and are considered high, but were similar to those found by Ribeiro and Pereira (2010) and Quaresma et al. (2011) and lower than that reported by Silva et al. (2007) in Tifton 85 hay. There was no effect of $\mathrm{N}$ on the NDF in the four cuts 
(Figure 12). The NDF content of forage is what most influences consumption, and values above $600 \mathrm{~g}$ $\mathrm{kg}^{-1}$ may be negatively associated with forage intake (MERTENS, 1994; REZENDE et al., 2015; VAN
SOEST, 1994). Ataíde Júnior (2000) concluded that sheep consumed the maximum amount of Tifton 85 hay at a $38 \mathrm{~d}$ regrowth interval, and that thereafter there would be a limitation of consumption caused by the physical limitation of intake.

Figure 12. Effect of nitrogen on the average contents of neutral detergent fiber (NDF) in the dry matter of Tifton 85 in the four cuts.

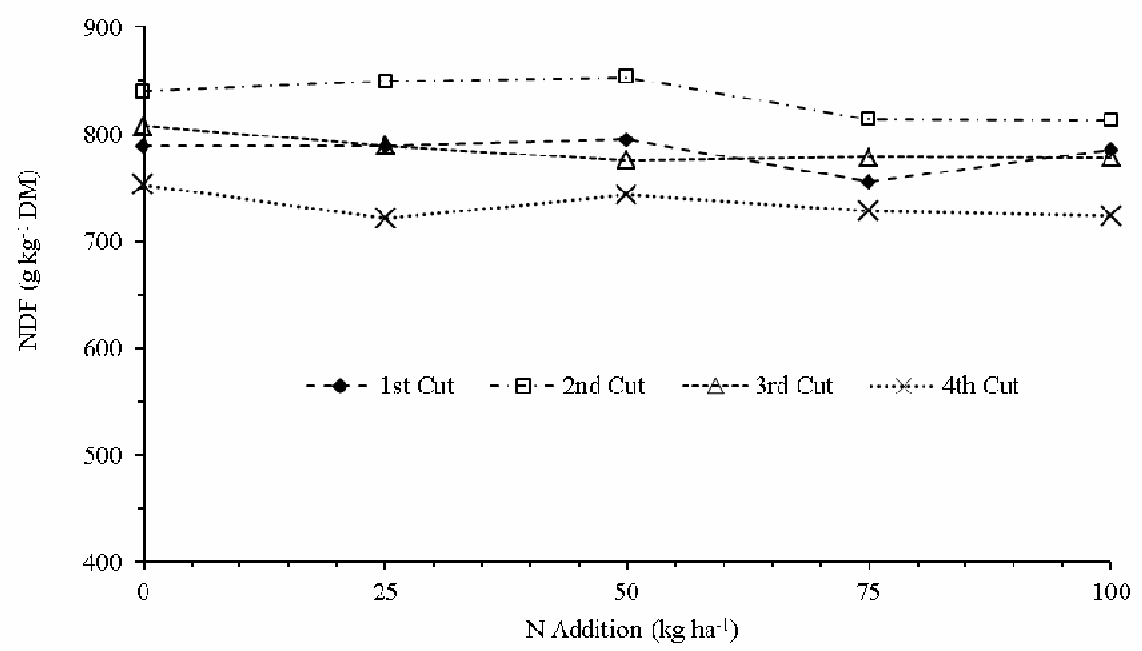

ADF ranged from 406.5 to $463.1 \mathrm{~g} \mathrm{~kg}^{-1} \mathrm{DM}$, with no difference among intervals or cuts (Table 2). The values were similar to those reported by Quaresma et al. (2011), who did not find differences between four cuts at $30 \mathrm{~d}$ intervals and $\mathrm{N}$ levels. Fontaneli et al. (2004) found a mean value of 354.0 $\mathrm{g} \mathrm{kg}^{-1}$ DM from three years of Tifton 85 samples from Rio Grande do Sul, measured with near infrared reflectance spectroscopy. The ADF values of this study were similar to those found by Oliveira et al. (2000) in the stems of Tifton 85 at different regrowth intervals. In the 3rd cut only, there was a quadratic effect of $\mathrm{N}$ application on ADF content (Figure 13).

CP content differed between regrowth intervals in the $1 \mathrm{st}, 3^{\text {rd }}$, and 4 th cuts (Table 2), with a higher content $(p<0.05)$ at the 28-d interval; at the 2 nd cut, there was no difference between intervals. The highest CP values (208.2 and $193.2 \mathrm{~g} \mathrm{~kg}^{-1} \mathrm{DM}$ for 28 and $35 \mathrm{~d}$, respectively) were recorded from the 4 th cut, which also had the lowest NDF values and higher LSR from the $28 \mathrm{~d}$ (1.27) and $35 \mathrm{~d}$ (1.62) intervals (Table 1). The CP values found in this study were higher than those found in other studies (RIBEIRO; PEREIRA, 2010; NERES et al., 2012; MARCHESAN et al., 2013). Many studies have reported that $\mathrm{CP}$ content increased with progressive increases of $\mathrm{N}$ application, and this study demonstrated a linear relationship between them in the 2nd, 3rd, and 4th cuts (Figure 14). However, at the 4th cut, CP content was higher, approximately $177.08 \mathrm{~g} \mathrm{CP} \mathrm{kg}^{-1}$ of DM without $\mathrm{N}$ to $224,34 \mathrm{~g}$ $\mathrm{CP} \mathrm{kg}{ }^{-1}$ of DM with $100 \mathrm{~kg} \mathrm{~N} \mathrm{ha}^{-1}(\mathrm{~PB}=177,08+$ $\left.0,47255^{*} \mathrm{~N}\right)$. 
Figure 13. Effect of nitrogen on the average contents of acid detergent fiber (ADF) in the dry matter of Tifton 85 in the four cuts.

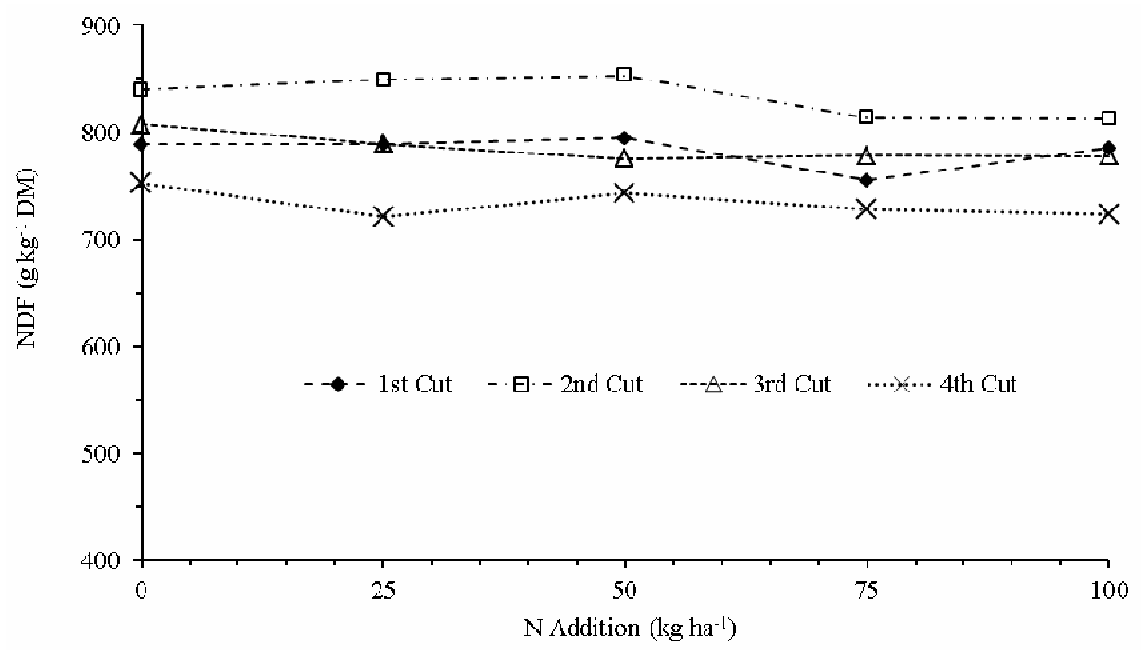

Figure 14. Effect of nitrogen on the contents of $\mathrm{CP}$ with regrowth ages of 28 and 35 days in four cuts of Tifton 85.

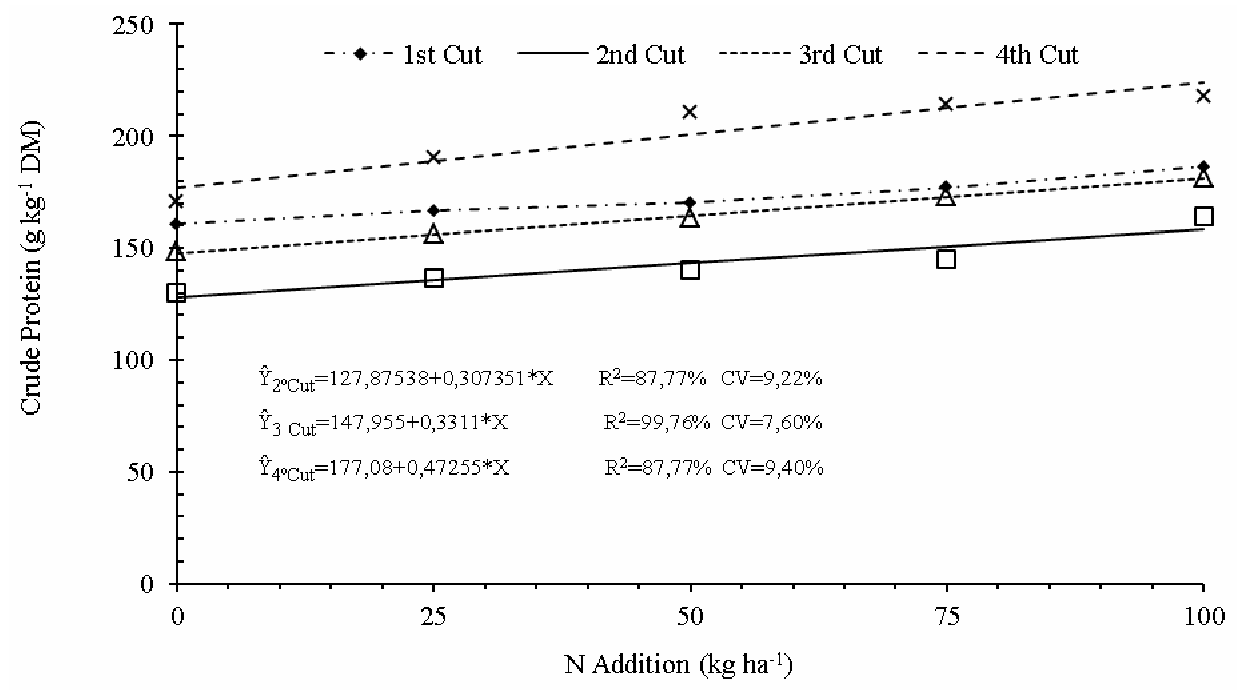

The diference of the amount of protein produced was of $151.65 \mathrm{~kg} \mathrm{CP} \mathrm{ha}^{-1}$ in the 4 th cut $(616.05 \mathrm{~kg}$ CP ha-1; $100 \mathrm{~kg} \mathrm{~N}$ ha-1) to the 1 st cut $(464.4 \mathrm{~kg}$ CP ha-1; $0 \mathrm{~kg} \mathrm{~N}$ ha-1), equivalent to $344.65 \mathrm{~kg}$ of soybean meal with $44 \% \mathrm{CP}$. At the $1 \mathrm{st}$, 2 nd and $3 \mathrm{rd}$ cut the difference was higher because de highest DMY (Table 1, Figure 3). Such an amount reflects a high capacity for one fertilized pasture to support meat or milk production (DIAS et al., 1998). Mazza et al. (2009) found linear increases in yield and CP content with $\mathrm{N}$ fertilization in Mombasa pasture grass (Panicum maximum) and Alderman et al.
(2011) and Quaresma et al. (2011) reported a similar effect in Tifton 85.

LIG content was significantly different $(p<$ $0.05)$ between the $28 \mathrm{~d}\left(61.2 \mathrm{~g} \mathrm{~kg}^{-1} \mathrm{DM}\right)$ and $35 \mathrm{~d}$ (88.8 $\left.\mathrm{g} \mathrm{kg}^{-1} \mathrm{DM}\right)$ intervals at the 4th cut (Table 2). The average contents were high compared to those reported in other studies, especially the 1st and 2nd cuts, although they were within the range of 5 to $25 \%$ of the cell wall in grasses reported by Sniffen et al. (1992). Silva and Queiroz (2009) suggested levels between 4 and $12 \%$, with an extreme of $20 \%$. N had no significant difference $(p>0.05)$ 
on LIG content among the cuts. LIG content is not measured equally by all methods. Bacha (2006) did not consider the acid detergent LIG, Klason LIG, or the LIG permanganate methods to be accurate. Sample preparation at temperatures higher than $55{ }^{\circ} \mathrm{C}$ also changes the apparent lignin content by forming complexes of HEM and LIG (OLIVEIRA, 2006; SILVA; QUEIROZ, 2009). Forage type also influences effective LIG content, as there are different types of LIG with different digestibility. Grasses and legumes with the same LIG content (SILVA; QUEIROZ, 2009) differ so much in digestibility with respect to LIG that accurate predictions are scarcely possible for tropical grasses (DETMANN et al., 2004), and LIG cannot represent the indigestible fraction of the diet (OLIVEIRA JUNIOR et al., 2004). According to Mertens (1994), it is easier to measure DM digestibility than intake; however, intake is more important than digestibility in assessing forage quality, because $60-90 \%$ of the differences in nutrient intake are related to ingestion, while $10-40 \%$ relate to differences in digestibility.

CEL content (Table 2) was greater $(p<0.05)$ at the 35 and $28-\mathrm{d}$ intervals at the 1 st and 4 th cuts respectively, with no differences at the 2 nd and 3rd cuts. CEL content ranged between 278.3 and $466.7 \mathrm{~g} \mathrm{~kg}^{-1} \mathrm{DM}$, similar to those found by Aguiar et al. (2006). There was no effect $(p>0.05)$ of $\mathrm{N}$ application on CEL levels.

There was no significant difference $(p>0.05)$ in HEM content between intervals and cuts (Table 2 ), nor was there an effect of $\mathrm{N}$. The values ranged from 266.8 to $378.5 \mathrm{~g} \mathrm{~kg}^{-1} \mathrm{DM}$, which are higher than those reported by Aguiar et al. (2006) from other tropical grasses. The degree of bioavailability of CEL and HEM to rumen microorganisms is variable and is linked to the degree of lignification and Maillard reactions (VAN SOEST, 1994), which produce physical and chemical interactions between carbohydrates and phenolic compounds; therefore, it is difficult to establish a standard for comparing digestibility (DETMANN et al., 2008).
IVDDM differed between the 28 and $35 \mathrm{~d}$ regrowth intervals in the 1 st and 2 nd cuts, both of which had higher digestibility at the 35-d interval. In the 1 st cut, the high rainfall in the last week before harvest at $35 \mathrm{~d}$ enabled the rapid development of young plant tissues (Figure 1). In the 2nd cut, many caterpillars (Spodoptera frugiperda JE Smith) partially defoliated plots with the 28-d interval, which is reflected in a significantly higher LSR (1.02 vs. 1.41) at the $35-d$ interval (Table 2). In the 1st and 2nd cuts, IVDDM was lower than that reported by Corriher et al. (2007) over two years of an experiment, but the 3rd and 4th cuts were similar. The NDF of Tifton 85 has less LIG and polysaccharides linked by ether and ferulic acid, which enhances rumen microbial digestion of this forage (CORRIHER et al., 2007). These authors found seasonal variation of IVDDM in Tifton 85, which might explain the higher digestibility in the 3rd and 4th cuts (Table 2).

According to formula $\mathrm{TDN}=87.84-0.70 \times$ ADF, proposed by Rodrigues (2009), estimated levels for the $1 \mathrm{st}, 2 \mathrm{nd}, 3^{\text {rd }}$, and 4 th cut at the $28-\mathrm{d}$ interval were $57.9 \%, 53.3 \%, 59.0 \%$, and $55.8 \%$, respectively, with an average of $56.5 \%$. For cuts at the 35 -d interval, estimates were $55.4 \%, 51.4 \%$, $59.4 \%$, and $57.5 \%$, respectively, with an average of $55.9 \%$. Factors that lower the ADF content, such as $\mathrm{N}$ and all conditions that affect the availability and absorption by the forage, as well as the cutting or grazing interval, also change the TDN level in Tifton 85 .

\section{Conclusions}

The application of $100 \mathrm{~kg} \mathrm{~N} \mathrm{ha}^{-1}$ after each cut promoted greater DMY and better forage quality of Tifton 85, with higher LER, canopy height, SL, and LL and dry matter production.

Cutting at $28 \mathrm{~d}$ of regrowth (vs. $35 \mathrm{~d}$ ) provided better bromatological values and qualitative feature in Tifton 85 forage. 
$\mathrm{DM} \mathrm{kg}^{-1} \mathrm{~N} \mathrm{ha}^{-1}$ was highest with $200 \mathrm{~kg} \mathrm{ha}^{-1} \mathrm{~N}$ at the $28 \mathrm{~d}$ regrowth interval and $100 \mathrm{~kg} \mathrm{ha}^{-1} \mathrm{~N}$ at the 35-d interval, when $\mathrm{N}$ was applied after each of four cuts.

Regrowth intervals of 28 and $35 \mathrm{~d}$ produced forage with similar digestibility.

\section{References}

AGUIAR, E. M.; LIMA, G. F. C.; SANTOS, M. V. F.; CARVALHO, F. F. R.; GUIM, A.; MEDEIROS, H.; BORGES, A. Q. Rendimento e composição químicobromatológica de fenos triturados de gramíneas tropicais. Revista Brasileira de Zootecnia, Viçosa, MG, v. 35, n. 6, p. 2226-2233, 2006.

ALDERMAN, P. D.; BOOTE, K. J.; SOLLENBERGER, L. E. Regrowth dynamics of 'Tifton 85 ' bermudagrass as affected by nitrogen fertilization. Crop Science, Madison, v. 51, n.4, p.1716-1726, 2011.

ANDERSON, W. F.; CASTER, M. D.; BALDWIN, B. S. Improvement of perennial forage species as feedstock for bioenergy. In: VERNIERRIS, W. (Ed.). Genetic improvement of bioenergy crops. Lincoln: University of Nebraska/USDA-ARS/UNL Faculty, 2008. p. 309-345.

ATAÍDE JÚNIOR, J. R.; PEREIRA, O. G.; GARCIA, R.; VALADARES FILHO, S. C.; CECON, P. R.; FREITAS, E. V. V. Valor nutritivo do feno de capimtifton 85 (Cynodon spp.) em diferentes idades de rebrota, em ovinos. Revista Brasileira de Zootecnia, Viçosa, MG, v. 29, n. 6, p. 2193-2199, 2000. Suplemento 2.

BACHA, C. B. Determinação do teor de lignina em amostras de gramineas ao longo do crescimento através de três métodos analiticos e implicações com as equações de "Cornell net carboydrate and protein system. 2006. Dissertação (Mestrado em Medicina Veterinária) Universidade de São Paulo, Pirassununga.

CAVIGLIONE, J. H.; KIIHL, L. R. B.; CARAMORI, P. H.; OLIVEIRA, D. Cartas climáticas do Paraná. Londrina: IAPAR, 2000. Disponível em: <http://www.iapar.br/ modules $/$ conteudo/conteudo.php? conteudo $=677>$. Acesso em: 10 abr. 2011.

CORRIHER, V. A.; HILL, G. M.; ANDRAE, J. G.; FROETSCHEL, M. A.; MULLINIX JUNIOR, B. G. Cow and calf performance on Coastal or Tifton 85 Bermudagrass pastures with Aeschynomene creep-grazing paddocks. Journal of Animal Science, Champaign, v. 85, n. 10, p. 2762-2771, 2007.
CUTRIM JUNIOR, J. A. A.; BEZERRA, A. P.; FARIAS, S. F.; AQUINO, R. M. S.; SOMBRA, W. A.; ANDRADE, R. R.; CÂNDIDO, M. J. D. Morfofisiologia do capimtifton 85 manejado intensivamente sob corte. Acta Tecnológica, São Luis, v. 9, n. 1, p. 62-69, 2014.

DETMANN, E.; MAGALHÃES, K. A.; VALADARES FILHO, S. C.; PAULINO, M. F.; HENRIQUES, L. T. Desenvolvimento de um submodelo bicompartimental para estimação da fração digestível da proteína bruta em bovinos a partir da composição química dos alimentos. Revista Brasileira de Zootecnia, Viçosa, MG, v. 37, n. 12, p. 2215-2221, 2008.

DETMANN, E.; ZERVOUDAKIS, J. T.; CABRAL, L. S.; ROCHA JÚNIOR, V. R.; VALADARES FILHO, S. C.; QUEIROZ, A. C.; PONCIANO, N. J.; FERNANDES, A. M. Validação de equações preditivas da fração indigestível da fibra em detergente neutro em gramíneas tropicais. Revista Brasileira de Zootecnia, Viçosa, MG, v. 33, n. 6, p. 1866-1875, 2004. Suplemento 1.

DIAS, P. F.; ROCHA, G. P.; OLIVEIRA, A. I. G.; PINTO, J. C.; ROCHA FILHO, R. R.; SOUTO, S. M. Produtividade e qualidade de gramíneas forrageiras tropicais sob adubação nitrogenada no final do período das águas. Pesquisa Agropecuária Brasileira, Brasília, v. 33, n. 7, p. 1191-1197, 1998.

DITTRICH, J. R.; CARVALHO, P. C. F.; MORAES, A.; LUSTOSA, S. B. C.; SILVEIRA, E. O.; OLIVEIRA, E. B. Preferência de eqüinos em pastejo: efeito da altura do dossel de gramíneas do gênero Cynodon. Archives of Veterinary Science, Curitiba, v. 10, n. 2, p. 61-67, 2005.

EMPRESA BRASILEIRA DE PESQUISA AGROPECUÁRIA - EMBRAPA. Embrapa solos. Sistema brasileiro de classificação de solos. 2. ed. Rio de Janeiro: EMBRAPA-SPI, 2006. 306 p.

FERRÃO, G. E.; CERRI, C. C.; FEIGL, B. J.; FEIGL, B. J.; SIQUEIRA NETO, M. Emissões de N2O de fertilizantes nitrogenados no milho cultivado no Cerrado. In: REUNIÃO BRASILEIRA DE FERTILIDADE DO SOLO E NUTRIÇÃO DE PLANTAS, 23., 2010, Guarapari. Anais... Guarapari: Fertibio, 2010. CD-ROM.

FERREIRA, D. F. Sisvar: a computer statistical analysis system. Ciência e Agrotecnologia, Lavras, v. 35, n. 6, p. 1039-1042, 2011.

FONTANELI, R. S.; SCHEFFER-BASSO, S. M.; DÜRR, J. W.; APPELT, J. V.; BORTOLINI, F.; HAUBERT, F. A. Predição da composição química de Bermudas (Cynodon spp.) pela espectroscopia de reflectância no infravermelho próxima. Revista Brasileira de Zootecnia, Viçosa, MG, v. 33, n. 4, p. 838-842, 2004. 
INSTITUTO AGRONÔMICO DO PARANÁ - IAPAR. Sugestão de adubação e calagem para culturas de interesse econômico no estado do Paraná. Londrina: Iapar, , 2003. 30 p. (Circular técnica, 128).

LATAWIEC, A. E.; STRASSBURG, B. B. N.; VALENTIM, J. F.; RAMOS, F.; ALVES-PINTO, H. N. Intensification of cattle ranching production systems: socioeconomic and environmental synergies and risks in Brazil. Animal, Cambridge, v. 8, n. 8, p. 1255-1263, 2014.

LOBATO, J. F. P.; FREITAS, A. K.; DEVINCENZI, T.; CARDOSO, L. L.; TAROUCO, J. U.; VIEIRA, R. M.; DILLENBURG, D. R.; CASTRO, I. Brazilian beef produced on pastures: Sustainable and healthy. Meat Science, Champaign, v. 98, n. 3, p. 336-345, 2014.

MACHADO, J. M.; ROCHA, M. G. da; QUADROS, F. L. F.; CONFORTIN, A. C. C.; SANTOS, A. B.; SICHONANY, M. J. O.; RIBEIRO, L. A.; ROSA, A. T. N. Morphogenesis of native grasses of Pampa Biome under nitrogen fertilization. Revista Brasileira de Zootecnia, Viçosa, v. 42, n. 1, p. 22-29, 2013.

MARCHESAN, R.; PARIS, W.; ZIECH, M. F.; PROHMANN, P. E. F.; ZANOTTI, J.; HARTMANN, D. V. Produção e composição química-bromatológica de Tifton 85 (Cynodon dactylon L. Pers) sob pastejo contínuo no período hibernal. Semina: Ciências Agrárias, Londrina, v. 34, n. 4, p. 1933-1942, 2013.

MAZZA, L. M.; POGGERE, G. C.; FERRARO, F. P.; RIBEIRO, C. B.; CHEROBIM, V. F.; MOTTA, A. C. V.; MORAES, A. Adubação nitrogenada na produtividade e composição química do capim mombaça no primeiro planalto paranaense. Scientia Agraria, Curitiba, v. 10, n. 4, p. 257-265, 2009.

MERTENS, D. R. Regulation of forage intake. In: FAHEY, G. C.; COLLINS JR, M.; MERTENS, D. R.; MOSER L. E. (Ed.). Forage quality evaluation and utilization. Madison: American Society of Agronomy, Crop Science Society of America, and Soil Science Society of America, 1994. p. 450-493.

MONTEIRO, A. L. G.; MORAES, A.; CARVALHO, P. C. F. Caracterização dos sistemas integrados de agricultura-pecuária. In: MORAES, A.; CARVALHO, P. C. F.; SILVA, H. A.; JANSSEN, H. P. (Ed.). Produção de leite em sistemas integrados de agricultura-pecuária. Curitiba: EMATER, 2008. p. 13-43.

MOREIRA, A. L.; FAGUNDES, J. L.; YOSHIHARA, E.; BACKES, A. A.; BARBOSA, L. T.; OLIVEIRA JUNIOR, L. F. G.; SANTOS, G. R. A.; SANTOS, M. A. S. A. Acúmulo de forragem em pastos de Tifton
85 adubados com nitrogênio e manejados sob lotação contínua. Semina: Ciências Agrárias, Londrina, v. 5, n. 36, p. 2275-2286, 2015.

NERES, M. A.; CASTAGNARA, D. D.; MESQUITA, E. E.; JOBIM, C. C.; TRÊS, T. T.; OLIVEIRA, S. R.; OLIVEIRA, A. A. M. A. Production of tifton 85 hay overseeded with white oats or ryegrass. Revista Brasileira de Zootecnia, Viçosa, MG, v. 40, n. 8, p. 1638 1644, 2011.

NERES, M. A.; CASTAGNARA, D. D.; SILVA, F. B.; OLIVEIRA, P. S. R.; MESQUITA, E. E.; BERNARDI, T. C.; GUARIANTI, A. J.; VOGHT, A. S. L. Características produtivas, estruturais e bromatológicas dos capins Tifton 85 e Piatã e do feija-guandu cv. Super N, em cultivo singular ou em associação. Ciência Rural, Santa Maria, v. 42, n. 5, p. 862-869, 2012.

OLIVEIRA, A. A. A. de. Efeito da temperatura de pré-secagem na digestibilidade e nos fracionamentos da proteína e do carboidrato de gramíneas tropicais. 2006. Dissertação (Mestrado em Ciência Animal) Universidade Federal de Mato Grosso do Sul, Campo Grande.

OLIVEIRA,A.P.P.; ROSSIELO, R. O.P.; GALZERANO, L.; COSTA JUNIOR, J. B. G.; SILVA, R. P.; MORENZ, M. J. F. Respostas do capim-Tifton 85 à aplicação de nitrogênio: cobertura do solo, índice de área foliar e interceptação da radiação solar. Arquivo Brasileiro de Medicina Veterinária e Zootecnia, Belo Horizonte, v. 62, n. 2, p. 429-438, 2010.

OLIVEIRAJUNIOR, R. C.; PIRES, A. V.; FERNANDES, J. J. R.; SUSIN, I.; SANTOS, F. A. P.; NASCIMENTO FILHO, V. F.; ARAÚJO, R. C. Avaliação de indicadores para estimar a digestibilidade dos nutrientes em novilhos nelore alimentados com dietas contendo alto teor de concentrado e fontes nitrogenadas. Revista Brasileira de Zootecnia, Viçosa, MG, v. 33, n. 3, p. 749-758, 2004.

OLIVEIRA, M. A.; PEREIRA, O. G.; HUAMAN, C. A. M.; GARCIA, R.; GOMIDE, J. A.; CECON, P. R.; SILVEIRA, P. R. Características morfogênicas e estruturais do capim-bermuda Tifton 85 (Cynodon spp.) em diferentes idades de rebrota. Revista Brasileira de Zootecnia, Viçosa, MG, v. 29, n. 6, p. 1939-1948, 2000. Suplemento 1.

PACIULLO, D. S. C.; AROEIRA, L. J. M.; MORENZ, M. J. F.; HEINEMANN, A. B. Morfogênese, características estruturais e acúmulo de forragem em pastagem de Cynodon dactylon, em diferentes estações do ano. Ciência Animal Brasileira, Goiânia, v. 6, n. 4, p. 233-241, 2005. 
PEDREIRA, M. S.; PRIMAVESI, O. Impacto da produção animal sobre o ambiente. In: BERCHIELLI, T. T.; PIRES, A. V.; OLIVEIRA, S. G. (Ed.). Nutrição de ruminantes. Jaboticabal: Funep, 2006. p. 497-511.

PEREIRA, O. G.; ROVETTA, R.; RIBEIRO, K. G.; SANTOS, M. E. R.; FONSECA, D. M.; CECON, P. R. Características morfogênicas e estruturais do capimtifton 85 sob doses de nitrogênio e alturas de corte. Revista Brasileira de Zootecnia, Viçosa, MG, v. 40, n. 9, p. 1870-1878, 2011.

PREMAZZI, L. M.; MONTEIRO, F. A.; CORRENTE, J. E. Tillering of tifton 85 bermudagrass in response to nitrogen rates and time of application after cutting. Scientia Agrícola, Piracicaba, v. 60, n. 3, p.565-571, 2003.

PREMAZZI, L. M.; MONTEIRO, F. A.; OLIVEIRA, R. F. Crescimento do capim-bermuda tifton 85 sumetido à adubação nitrogenada após o corte. Revista Brasileira de Zootecnia, Viçosa, MG, v. 4, n. 3, p. 518-526, 2011.

QUARESMA, J. P. S.; ALMEIDA, R. G.; ABREU, J. G.; CABRAL, L. S.; OLIVEIRA, M. A.; CARVALHO, D. M. G. Produção e composição bromatológica do capimtifton 85 (Cynodon spp.) submetido a doses de nitrogênio. Acta Scientiarum Animal Sciences, Maringá, v. 33, n. 2, p. 145-150, 2011.

REZENDE, A. V.; RABELO, F. H. S.; RABELO, C. H. S.; LIMA, P. P.; BARBOSA, L. A.; ABUD, M. C.; SOUZA, F. R. C. Características estruturais, produtivas e bromatológicas dos capins Tifton 85 and Jiggs fertilizados com alguns macronutrientes. Semina: Ciências Agrárias, Londrina, v. 36, n. 3, p. 1507-1518, 2015.

RIBEIRO, K. G.; PEREIRA, O. G. Valor nutritivo do capim-tifton 85 sob doses de nitrogênio e idades de rebrotação. Veterinária e Zootecnia, Botucatu, v. 17, n. 4, p. 560-567, 2010.

RIBEIRO, K. G.; PEREIRA, O. G.; VALADARES FILHO, S. C.; GARCIA, R.; CABRAL, L. S. Caracterização das frações que constituem as proteínas e os carboidratos, e respectivas taxas de digestão, do feno de capim Tifton 85 de diferentes idades de rebrota. Revista Brasileira de Zootecnia, Viçosa, MG, v. 30, p. 589-595, 2001. Suplemento 2.

ROCHA, G. P.; EVANGELISTA, A. R.; LIMA, J. A. de. Nitrogênio na produção de matéria seca, teor e rendimento de proteína bruta de gramíneas tropicais. Pasturas Tropicales, Cali, v. 22, n. 1, p. 4-8, 2000.

RODRIGUES, R. C. Avaliação químico-bromatológica de alimentos produzidos em terras baixas para nutrição animal. Pelotas: EMBRAPA, 2009. 31 p. (Documentos, 270).
SILVA, D. J.; QUEIROZ, A. C. de. Análise de alimentos: métodos químicos e biológicos. 3. ed. Viçosa, MG: UFV, 2009. 235 p.

SILVA, D. R. G.; COSTA, K. A. P.; FAQUIN, V.; OLIVEIRA, I. P.; BERNARDES, T. F. Doses e fontes de nitrogênio na recuperação das características estruturais e produtivas do capim-marandu. Revista Ciência Agronômica, Fortaleza, v. 44, n. 1, p. 184-191, 2013.

SILVA. E. A.; BERCHIELLI, T. T.; REIS, R. A. Teores de proteína bruta para bovinos alimentados com feno de tifton 85: consumo e digestibilidades total e parcial. Revista Brasileira de Zootecnia, Viçosa, MG, v. 36, n. 1, p. 237-245, 2007.

SNIFFEN, C. J.; O’CONNOR, J. D.; VAN SOEST, P. J.; FOX, D. G.; RUSSEL, J. B. A net carbohydrate and protein system for evaluating cattle diets: II. Carbohydrate and protein availability. Journal of Animal Science, Champaign, v. 70, n.11, p.3562-3577, 1992.

SOLLENBERGER, L. E. Sustainable production systems for Cynodon species in the subtropics and tropics. Revista Brasileira de Zootecnia, Viçosa, MG, v. 37, p. 85-100, 2008. Suplemento Especial.

TAMMINGA, S. A. review on environmental impacts of nutritional strategies in ruminants. Journal Animal Science, Champaign, v. 74, n. 12, p. 3112-3124, 1996.

VAN SOEST, P. J. Nutritional ecology of the ruminant. $2^{\text {th }}$ ed. Ithaca: Cornell University Press, 1994. 476 p.

VENDRAMINI, J. M. B.; SOLLENBERGER, L. E.; ADESOGAN, A. T.; DUBEUX JUNIOR, J. C. B.; INTERRANTE, S. M.; STEWART JUNIOR, R. L.; ARTHINGTON, J. D. Protein fractions of Tifton 85 and ryegrass due to sward management practices. Agronomy Journal, Madison, v. 100, n. 2, p. 463-469, 2008a.

VENDRAMINI, J. M. B.; SOLLENBERGER, L. E.; DUBEUX JUNIOR, J. C. B.; INTERRANTE, S. M.; STEWART JUNIOR, R. L.; ARTHINGTON, J. D. Sward management effects on forage component responses in a production system for early weaned calves. Agronomy Journal, Madison, v. 100, n. 6, p. 1781-1786, 2008 b.

VILELA, D.; PAIVA, P. C. A.; LIMA, J. A.; CARDOSO, R. C. Morfogênese e acúmulo de forragem em pastagem de Cynodon dactylon cv. coastcross em diferentes estações de crescimento. Revista Brasileira de Zootecnia, Viçosa, MG, v. 34, n. 6, p. 1891-1896, 2005. 
